Conservation
Division of Buildings and

Community Systems

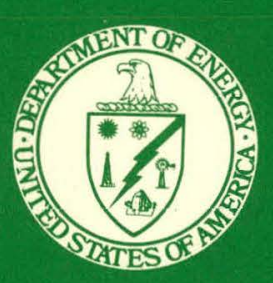

\section{ORNL/CON-5}

MASTER

\title{
An Efficiency Evaluation and Consumer Economic Analysis of Domestic Water Heaters
}
G. G. Slaughter
D. E. Spann

OAK RIDGE NATIONAL LABORATORY OPERATED BY UNION CARBIDE CORPORATION - FOR THE DEPARTMENT OF ENERGY 


\section{DISCLAIMER}

This report was prepared as an account of work sponsored by an agency of the United States Government. Neither the United States Government nor any agency Thereof, nor any of their employees, makes any warranty, express or implied, or assumes any legal liability or responsibility for the accuracy, completeness, or usefulness of any information, apparatus, product, or process disclosed, or represents that its use would not infringe privately owned rights. Reference herein to any specific commercial product, process, or service by trade name, trademark, manufacturer, or otherwise does not necessarily constitute or imply its endorsement, recommendation, or favoring by the United States Government or any agency thereof. The views and opinions of authors expressed herein do not necessarily state or reflect those of the United States Government or any agency thereof. 


\section{DISCLAIMER}

Portions of this document may be illegible in electronic image products. Images are produced from the best available original document. 


\title{
Printed in the United States of America. Available from National Technical Information Service
}

U.S. Department of Commerce 5285 Port Royal Road, Springfield, Virginia 22161

Price: Printed Copy $\$ 5.25$; Microfiche $\$ 3.00$

\begin{abstract}
This report was prepared as an account of work sponsored by an agency of the United States Government. Neither the United States Government nor any agency thereof, nor any of their employees, contractors, subcontractors, or their employees, makes any warranty, express or implied, nor assumes any legal liability or responsibility for any third party's use or the results of such use of any information, apparatus, product or process disclosed in this report, nor represents that its use by such third party would not-infringe privately owned rights.
\end{abstract}


Contract No. W-7405-eng-26

\section{AN EFFICIENCY EVALUATION AND CONSUMER ECONOMIC ANALYSIS} OF DOMESTIC WATER HEATERS

G. G. Slaughter

Physics Division

and

D. E. Spann

Energy Division

Department of Energy

Division of Buildings and Community Systems

Date Published: September 1978

OAK RIDGE NATIONAL LABORATORY

This report was prepared as an account of work sponsored by the United States Govemment. Neither the United States nor the United States Department of Energy, not any of thels employees, nor any of their conlisulurs, subcontractors, or their employees, makes any warranty, express or implied, or assumes any legal liability or responsibility for the accuracy completeress or usefulness of any information. apparatus, produet ar pouses ass of any information, apparatus, product ar infringe privaltely uwned reghts.

Oak Ridge, Tennessee 37830 operated by

UNION CARBIDE CORPORATION

for the

DEPARTMENT OF ENERGY 


\section{THIS PAGE}

\section{WAS INTENTIONALLY \\ LEFT BI.ANK}


CONTENTS

ABSTRACT .. . . . . . . . . . . . . . . . . . . . 1

1. INTRODUCTION . . . . . . . . . . . . . . . . . . . 1

2. CHARACTERIZATION OF STORAGE-TYPE WATER HEATERS . . . . . . . . 3

2.1 Gas-Fired Water Heaters . . . . . . . . . . . . . . . . 5

2.1.1 Description . . . . . . . . . . . . . . . . . . 5

2.1.2 Characterization of gas-fired water heaters . . . 7

2.1.3 Further modifications to improve efficiency and energy conservation ............ . 17

2.1.4 Power burner tests.............. . 20

2.2 Electric Water Heaters .. . . . . . . . . . . . . . 21

2.2.1 Description ................... . 21

2.2.2 Characterization of electric water heaters . . . 23

2.3 Efficiency Evaluation of Water Heaters: Appliance

Efficiency and Service Efficiency . . . . . . . . . 24

3. ENERGY CONSERVATION PRACTICES IN THE HOME . . . . . . . . . . 35

4. ECONOMIC ANALYSIS OF STORAGE-TYPE WATER HEATERS . . . . . . . 39

4.1 Gas-Fired Water Heaters . . . . . . . . . . . . . . . . . 39

4.2 Electric Water Heaters . . . . . . . . . . . . . . . . 41

4.3 Indirect Energy Usage of Storage-Type Water Heaters . . . 44

5. SUMMARY AND CONCLUSIONS . . . . . . . . . . . . . . . 47

REFERENCES ........................... 49 
THIS PAGE

WAS INTENTIONALLY

LEFT BLANK 
1 Main burner efficiencies for gas-fired water heaters . . . 4

2 Airflow rates and excess-air ratios for a gas-fired water heater . . . . . . . . . . . . . . . . 8

3 Heat loss rates and gas consumption during standby of gas-fired water heaters . . . . . . . . . . . . . 14

4 Jacket heat loss rate for a 50-gal gas-fired water heater . 19

5 Pilot heat-transfer efficiency for gas-fired water heater with stack restricted by 5/16-in. orifice . . . . . . . 19

6 Standby heat losses of electric water heaters . . . . . 26

7 Full-load efficiency of 30 - and 66-gal electric water heaters $\left(55^{\circ} \mathrm{F}\right.$ input temperature) . . . . . . . . . . 27

8 Operating costs and savings with pilot off and flue open or blocked during standby for a gas-fired water heater . . . . 40

$9 \quad$ Operating costs of as-received and modified gas-fired water heater while delivering $75 \mathrm{gal} /$ day of $150^{\circ} \mathrm{F}$ hot water . . . 42

10 Cost of standby heat losses for electric water heater . . . 43

11 Cost per month of cuntinuous air conditioning to remove water heater jacket loss from conditioned space . . . . . . 46 
THIS PAGE

WAS INTENTIONALLY

LEFT BLANK 
Gas-fired water heater .. . . . . . . . . . 6

2 Gas-fired water heater: input, flue loss (pilot only on), flue loss (pilot off), available and flue-to-water-tank heat rates, and pilot heat-exchange efficiency vs water tank temperature................... . 10

3 Gas-fired water heater: jacket, flue-to-water-tank, and net tank loss heat rates vs water tank temperature . . . . . 11

4 Gas-fired water heater: total heat loss rates vs water tank temperature for three operational configurations . . . 13

5 Gas-fired water heater:, service efficiency of main burner vs water tank temperature . . . . . . . . . . 16

6 Jacket heat loss rates for gas-fired water heater, as received and with retrofit insulation . . . . . . . . . 18

Fast-recovery-type 66-gal electric water heater . . . . . 22

8 Standby heat loss rates for electric water heaters vs water temperature with typical data points shown (ambient temperature $\left.=70^{\circ} \mathrm{F}\right)$. . . . . . . . . . . . . . . . 25

Appliance efficiencies of electric water heaters . . . . . 31 


\title{
AN EFFICIENCY EVALUATION AND CONSUMER ECONOMIC ANALYSIS OF DOMESTIC WATER HEATERS
}

\author{
G. G. Slaughter
}

D. E. Spann

\begin{abstract}
The performances of one gas-fired and two electric storage-type water heatcrs were characterized experimentally as a function of water tank temperature. For both types of heaters the application of additional insulation was highly cost effective. For the gas-fired water heater the pilot burner flue losses [92\% at a water temperature of $\left.150^{\circ} \mathrm{F}\left(65.6^{\circ} \mathrm{C}\right)\right]$ were reduced in a costeffective manner by either pilot orifice restriction or flue blocking with electric ignition. In addition, an electrically powered burner, with flue modifications, increased the heat-exchange efficiency of the main burner from $72 \%$ to $85 \%$ at $160^{\circ} \mathrm{F}\left(71.1^{\circ} \mathrm{C}\right)$. The heat loss rate per unit of bare tank area is a useful number in assessing the energy conservation potential of a water heater.
\end{abstract}

\section{INTRODUCTION}

The United States of America has had the reputation among world travelers of a nation in which hot water is ubiquitously available in almost unlimited quantities. Regardless of the truth or falsity of this impression, the energy consumption of gas and electric water heaters is significant, in terms of both fuel and equivalent.dollars. In 1975, electric water heaters are estimated ${ }^{1}$ to have directly consumed $90 \times 10^{9}$ $\mathrm{kWh} \times\left(0.3 \times 10^{15} \mathrm{Btu}\right)$ at a total cost of $\$ 3$ billion (at $3.45 \$ / \mathrm{kWhr}$ ). At an estimated generation and distribution efficiency of $30 \%$, this usage accounted for $1.0 \times 10^{15} \mathrm{Btu}$ of energy consumption at the power station. Gas-fired water heaters are estimated to have consumed $1.0 \times 10^{15}$ Btu at a total cost of $\$ 1.9$ billion (at $2.0 \$ / \mathrm{MBtu}$ ). The total energy cost for gas and electric water heating of $\$ 5$ bililion, and primary consumption of $2 \times 10^{15} \mathrm{Btu}$, implies that large absolute savings 
in dollars and fuel are potentially possible with conservative use and improved water heaters. These large savings will be realized by homeowners if energy-conservative modifications or new equipment can be made economically advantageous. The major purpose of this study is to determine how this can be done. 


\section{CHARACTERIZATION OF STORAGE-TYPE WATER HEATERS}

Water heaters are installed in a wide variety of spaces, such as heated and unheated indoor spaces, garages, crawl spaces, and outdoor areas in mild climates. The use pattern of water heaters also varies widely in regard to throughput, frequency of hot water draws, and thermostat settings. These varying use patterns dictate variations in appropriate heater size. The most reasonable approach to obtaining performance data for water heaters of varying sizes under such a wide range of conditions is to measure, as a function of water temperature, the intrinsic properties of water heaters in the laboratory and to use these data to calculate the performance of water heaters under other conditions.

Some of the heat rates associated with the operation of water heaters vary drastically with water tank temperature. It is important, therefore, to make performance measurements in the laboratory at realistic operating temperatures. The actual average operating temperature of a water heater will depend upon the thermostat setting and use pattern, and the amount of cold water which is heated. In practice, this average temperature is close enough to the thermostat temperature setting that the term "hot water heater" is more realistic than redundant. Most of the time the water heater is heating a mixture of hot water and incoming cold water. This mixture has a temperature not very much below the thermostat setting. For example, the 50-gal gas-fired water heater is capable of heating $42 \mathrm{gal} / \mathrm{hr}$ from 55 to $150^{\circ} \mathrm{F}\left(12.8\right.$ to $\left.65.6^{\circ} \mathrm{C}\right)$ (see Table 1). This gas water heater can heat 75 gal of water per day from 55 to $150^{\circ} \mathrm{F}\left(12.8\right.$ to $\left.65.6^{\circ} \mathrm{C}\right)$ for the average family of four and supply most of the standby heat loss rate by only 2.22 hours of main burner operation per day. The remaining $91 \%$ of the time the water tank is at or near the thermostat temperature setting. It is clearly inappropriate to represent measurements taken at inlet water temperature, or the average of inlet water temperature and $150^{\circ} \mathrm{F}\left(65.6^{\circ} \mathrm{C}\right)$, as being applicable to this water heater operating at a $150^{\circ} \mathrm{F}\left(65.6^{\circ} \mathrm{C}\right)$ thermostat setting. 
Table 1. Main burner efficiencies for gas-fired water heaters ${ }^{a}$

\begin{tabular}{ccc}
\hline $\begin{array}{c}\text { Water temperature } \\
\left({ }^{\circ} \mathrm{F}\right)\end{array}$ & $\begin{array}{c}\text { Main burner efficiency } \\
(\%)\end{array}$ & $\begin{array}{c}\text { Recovery rate } \\
(\mathrm{gal} / \mathrm{hr})\end{array}$ \\
\hline 110 & 74 & 74.8 \\
130 & 73 & 54.3 \\
150 & 71 & 42.0 \\
\hline
\end{tabular}

$a_{\text {Efficiency }}=\frac{\text { input heat rate }- \text { total heat loss rate }}{\text { input heat rate }}$.

The 66-gal electric water heater tested has a lower recovery rate, but it is still in the standby mode of operation $82 \%$ of the time under the conditions specified.

Considerable effort was expended to measure heat loss rates directly, rather than inferring them from the difference between input and output heat rates. For example, the jacket heat loss rates for the heaters were measured for all temperatures of interest by allowing the heaters to heat the water to the maximum thermostat setting and subsequently measuring the time rate of temperature decay of the tank, with the heat source off and outlet valve clused. The fluo of the gas-fired water heater was blocked with an insulating material during this measurement to prevent flue loss. The gas-fired water heater pilot burner flue heat loss rate was determined by measuring the flow rate and temperature of the flue gas for all tank temperatures of interest. In addition, all of the heat rates for the gas-fired water heater were determined for all temperatures of interest by measuring the rate of temperature change of the tank under the proper conditions. All of these techniques yield heat rates and efficiencies as a function of water tank temperature. Some of these measurements were repeated using the classical technique of measuring the flow rate and temperature rise of water flowing through the heater. The results of the two different techniques agreed to within experimental error. Unfortunately, the classical techniques give the heat flows and efficiencies at unrealistically low water tank temperatures. 
The gas-fired water heater is considerably more complex thermodynamically than the electric water heater, and it spends a larger fraction of the time in the standby mode with only the pilot burner on. An investigation of the heat flow rates associated with pilot burner operation will effectively demonstrate all of the thermodynamic principles involved, with analysis of main burner operation and electric water heater operation forming a simpler subset.

\subsection{Gas-Fired Water Heaters}

\section{1 .1 Description}

The gas-fired water heater tested in the laboratory will be described since it is typical of the current state of commercial offerings (Fig. 1). The cylindrical water tank is 47.5 in. $(120.6 \mathrm{~cm})$ high and $18 \mathrm{in.}(45.7 \mathrm{~cm})$ in diameter, and has a central flue that is 3.75 in. $(9.52 \mathrm{~cm})$ in diameter. The nominal capacity is 50 gal $\left(0.189 \mathrm{~m}^{3}\right)$. Between the tank and the sheet metal outer jacket is 1 in. $(2.54 \mathrm{~cm})$ of glass fiber insulation. The pilot and main burners are at the bottom of the flue. They are controlled by a valve which has the positions "Off," "Pilot Only," and "On." A thermostat opens the main burner valve when the water temperature drops below the set point. A thermocouple heated by the pilot burner operates a solenoid valve, which shuts off the gas supply if the pilot burner goes out. The pilot burner consumes natural gas (in this case), which has a heat of combustion of $1030 \mathrm{Btu} / \mathrm{ft}^{3}$ $\left(3.84 \times 10^{7} \mathrm{~J} / \mathrm{m}^{3}\right)$, at a rate of $0.9 \mathrm{ft}^{3} / \mathrm{hr}\left(2.55 \times 10^{-2} \mathrm{~m}^{3} / \mathrm{hr}\right)$, for a pilot-only heat input rate of $924 \mathrm{Btu} / \mathrm{hr}(271 \mathrm{~W})$. The pilot and main burners consume $44.6 \mathrm{ft}^{3} / \mathrm{hr}\left(1.26 \mathrm{~m}^{3} / \mathrm{hr}\right)$, producing a heat input rate of $45,950 \mathrm{Btu} / \mathrm{hr}(13.5 \mathrm{~kW})$. A baffle in the flue induces turbulence in the hot flue gases and promotes heat exchange with the tank. A draft hood or draft divertcr at the tup of the heater decouples the flue from the stack or chimney, so that gusts of wind will not extinguish the pilot. For convenience, the water piping connections are at the top of the heater. The outlet for the hot water is at the top of the tank, whereas the inlet pipe is carried to the bottom of the tank with a dip tube 
ORNL- DWG 77-15748

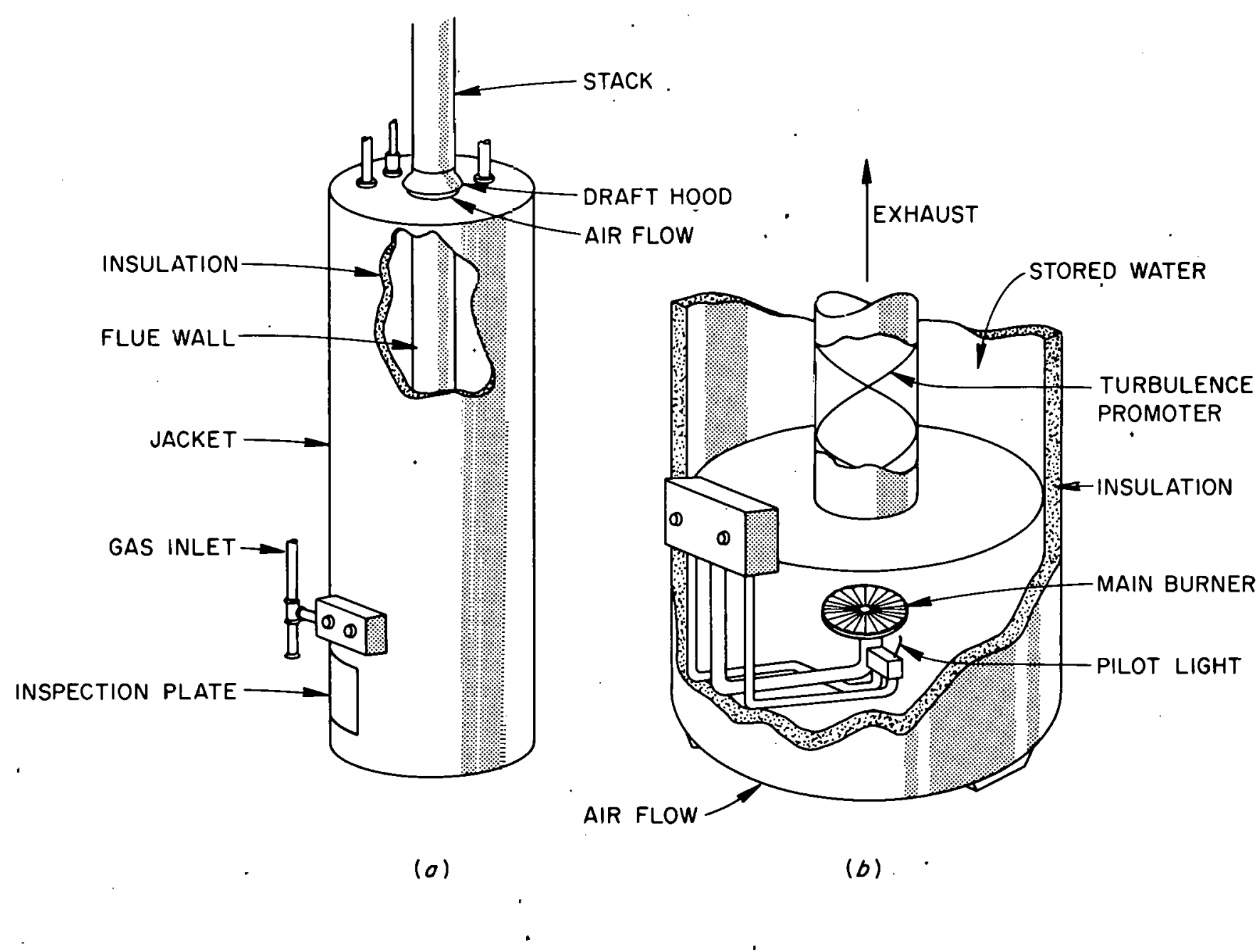

Fig. 1. Gaś-fired water heater. 
fitted with a diffuser, which discharges the cold water with minimum vertical velocity. This arrangement promotes stratification between the less dense hot water exiting at the top and the more dense cold water entering at the bottom. In practice, the exiting water remains hot until it is almost completely displaced by cold water. A temperature and pressure safety valve at the top of the heater and a drain cock at the bottom complete the fittings.

A critical look at the design of the heater is in order. The flue and airflow orifices are sized for the main burner, which burns about 50 times more gas per hour than the pilot burner. Since there is no provision for reducing the size of the orifices for pilot-only operation, it is expected that the pilot burner will operate with considerable excess air. The open flue in the middle of the tank can be expected to be a large heat-loss mechanism, especially if the burners are off. If the water tank temperature is above the surrounding ambient temperature, a natural draft will be induced in the flue, and ambient air will flow into the bottom of the flue to replace the less dense hot air rising from the top. The velocity of the flow should increase with increasing temperature difference. The draft hood will permit the eduction of considerably. more air from the installed space than the flow up the flue. With only 1 in. $(2.54 \mathrm{~cm})$ of glass fiber insulation, a substantial amount of heat will be lost through the jacket.

\subsubsection{Characterization of gas-fired water heaters}

The tank can interchange heat through two interfaces: the wall jacket interface and the wall - flue interface. The heat loss rate through the tank-wall - jacket interface varies directly with the temperature difference between the tank wall and the ambient temperature. The tank can either gain or lose heat through the wall - flue interface, depending upon the relative temperature of the wall and the gases in the flue. A complete characterization of the heater would include the heat input rate, the jacket heat loss rate, the interchange heat rate between the flue and the tank wall, and the flue heat loss rate, over the range of temperatures of interest and for all possible combinations of burners. 
The net heat rate of the water tank is the algebraic sum of the jacket wall heat rate and the wall - flue heat rate.

The combustion airflow rates during pilot burner operation establish the constraints upon heat transfer to the water tank. These flows are shown in Table 2 for the following conditions: no burners on, pilot burner on, and both pilot and main burners on. The airflow rate with no burners on is the only one which varies markedly with tank temperature. The airflow with the pilot burner on is a surprisingly large fraction of the airflow with the main burner on. With the pilot burner operating at excess-air ratios (air.supplied/air required) of about 50, the heat rate available to the tank falls rapidly as the tank temperature rises, because more of the heat is required merely to raise the temperature of the excess air. Even at room temperature, only 830 of the $924 \mathrm{Btu} / \mathrm{hr}$ (243 of $271 \mathrm{~W}$ ) are available because $94 \mathrm{Btu} / \mathrm{hr}(27.5 \mathrm{~W})$ are required to vaporize the water formed in the fuel combustion process. Under the highly diluted combustion conditions of the pilot burner operation, the heat of vaporization usually cannot be recovered. For example, the added water of combustion raised the dew point from the $43.5^{\circ} \mathrm{F}\left(6.4^{\circ} \mathrm{C}\right)$ of the incoming air to only $54.5^{\circ} \mathrm{F}\left(12.5^{\circ} \mathrm{C}\right)$.

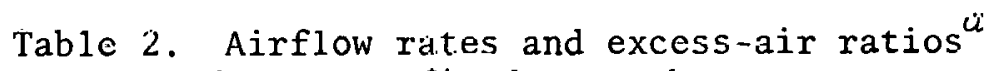
for a gas-fired water heater

\begin{tabular}{llccc}
\hline & \multicolumn{4}{c}{ Water temperature, ${ }^{\circ} \mathrm{F}$} \\
\cline { 2 - 5 } & 92.5 & 114.5 & 134.5 & 152.5 \\
\hline $\begin{array}{l}\text { Pilot and main burner off } \\
\quad \text { Airflow, ft }{ }^{3} / \mathrm{hr}\end{array}$ & 233.0 & 266.0 & 359.0 & 359.0 \\
$\begin{array}{l}\text { Pilot only on } \\
\text { Airflow, ft }{ }^{3} / \mathrm{hr}\end{array}$ & & & & \\
$\quad$ Excess-air ratio & 411.0 & 411.0 & 444.0 & 480.0 \\
$\begin{array}{l}\text { Pilot and main burner on } \\
\text { Airflow, ft }{ }^{3} / \mathrm{hr}\end{array}$ & 49 & 49 & 53 & 58 \\
$\quad$ Excess-air ratio & & & & \\
\hline
\end{tabular}

$a_{\text {Excess-air } \text { ratio }}=$ air supplied/air required for stoichiometric combustion. 
The heat available to the tank from the $924 \mathrm{Btu} / \mathrm{hr}(271 \mathrm{~W})$ input of the pilot burner is shown as the dashed curve in Fig. 2. As expected, it falls rapidly with tank temperature. The actual heat exchanged with the tank by the hot flue gases can be determined from the flue heat loss rate, which was measured as a function of water temperature. The difference between the input heat rate and the measured flue heat loss rate is the heat-exchange rate with the tank, and is shown in Fig. 2 . The scale at the right of Fig. 2 indicates the heat-exchange efficiency of the pilot as a function of temperature. The heat-exchange efficiency can approach $90 \%$ if the tank is at room temperature, but falls to $40 \%$ at $110^{\circ} \mathrm{F}\left(43.3^{\circ} \mathrm{C}\right)$ and $8 \%$ at $150^{\circ} \mathrm{F}\left(65.6^{\circ} \mathrm{C}\right)$. It is apparent from the heatexchange efficiency curve that, if the entering air is cold enough and the tank is hot enough, the "hot" flue gases will actually extract heat from the tank. This would occur if the ambient air were at $50^{\circ} \mathrm{F}\left(10^{\circ} \mathrm{C}\right)$ and the tank were above $137^{\circ} \mathrm{F}\left(58.3^{\circ} \mathrm{C}\right)$.

The flue heat loss rate with the flue open and the pilot burner off is also shown in Fig. 2. This rate has the same general shape as the "pilot on" flue heat loss rate curve, but is 340 to $460 \mathrm{Btu} / \mathrm{hr}$ (100 to $135 \mathrm{~W})$ less, and the difference increases with increasing water temperature.

Measurement of the jacket heat loss rate is necessary to completely characterize the pilot burner operational mode. This heat loss rate is obtained by completely blocking the flue and measuring the rate of temperature decay of the tank. The heat loss rate through the connecting piping is small compared to the jacket heat loss rate, and will be considered part of the jacket loss. The result of this jacket and piping heat loss rate measurement is shown in Fig. 3. The curve is closely linear over the temperature range of interest, but is highly nonlinear near room temperature (not shown). The wall - flue heatexchange rate is repeated from Fig. 2. The net heat rate of the water tank, which determines whether the water-tank temperature is increasing (positive heat rate) or decreasing (negative heat rate), is the algebraic sum of the heat rates at these two interfaces. This algebraic sum is also shown in Fig. 3. According to the calculations, at water temperatures above $112^{\circ} \mathrm{F}\left(44.4^{\circ} \mathrm{C}\right)$ the tank will decrease in temperature with only the 


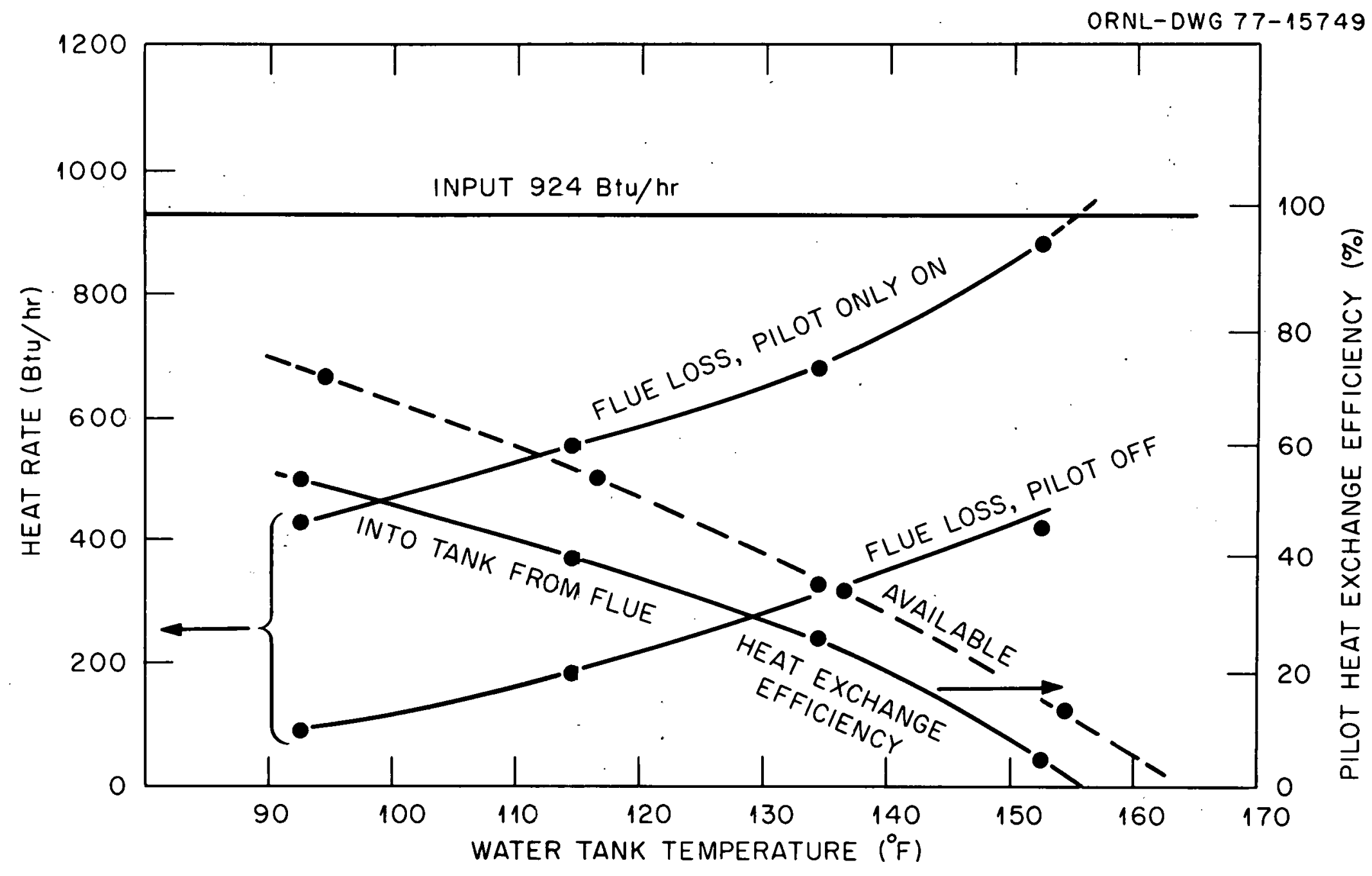

Fig. 2. Gas-fired water heater: infut, flue loss (pilot only on), flue loss (pilot off), available and flue-to-water-tank heat rates, and pilot heat-exchange efficiency vs water tank temperature. 


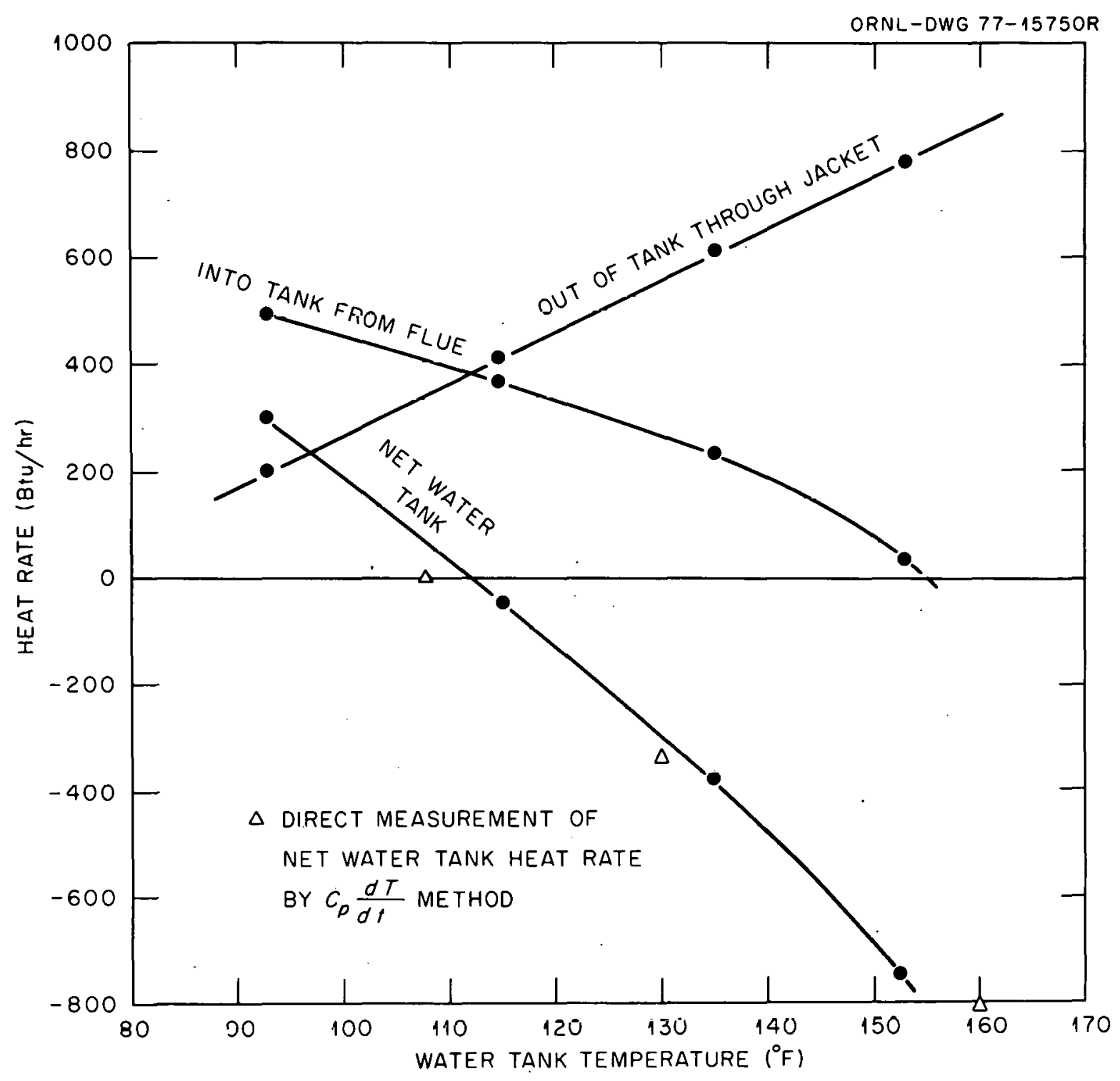

Fig. 3. Gas-fired water heater: jacket, flue-to-water-tank, and net tank loss heat rates vs water tank temperature. 
pilot burner on. The net heat rate of the tank was measured by the temperature-decay-rate method for three temperatures, and the results are indicated by triangles in Fig. 3. The water temperature at which the jacket heat loss rate was exactly balanced by the heat input rate from the flue was $108^{\circ} \mathrm{F}\left(42.2^{\circ} \mathrm{C}\right)$, approached from above and below, compared with the calculated value of $112^{\circ} \mathrm{F}\left(44.4^{\circ} \mathrm{C}\right)$, but the difference in heat rates is only about $40 \mathrm{Btu} / \mathrm{hr}(11.7 \mathrm{~W})$. The agreement of the two methods is considered adequate and within the bounds of experimental error.

The total standby heat loss rate is the sum of the jacket heat loss rate and the flue heat loss rate (Figs. 2 and 3). Figure 4 shows these sum curves for the situations of flue blocked, flue open and pilot off, and flue open and pilot on. The water heater can be thought of as operating in three different configurations corresponding to the three curves. For the flue-blocked curve, the heater would have an external electrical or mechanical means of opening the flue and an electrical means of igniting the main burner when necessary; the flue remains blocked during standby conditions. The heat loss rate during standby is that of just the jacket and is supplied by intermittent firings of the main burner operating at a heat-exchange efficiency of about $73 \%$. For the flue-open and pilot-off curve, operation is the same except that the flue is open during standby conditions. The total heat loss rate is the sum of the jacket heat loss rate and the pilot-off flue heat loss rate, and must be supplied by the main burner. For the flue-open and pilot-on curve, the heater is operated as it comes from the factory, with a standing pilot and with the flue always open. The total heat loss rate is the sum of the jacket heat loss rate and the pilot-on flue heat loss rate; the main burner must supply the net water tank heat loss rate.

The curves show that the energy savings for the flue-blocked configuration (as compared to the as-received configuration) increase with increasing water temperature, while the savings for the electrical ignition only (flue open, pilot off) tend to remain relatively constant. Note that the total heat loss rate for the pilot-on case is given alternatively by the sum of the net water heat loss rate (Fig. 4) and the pilot-input combustion heat rate. In other words, the pilot is supplying 


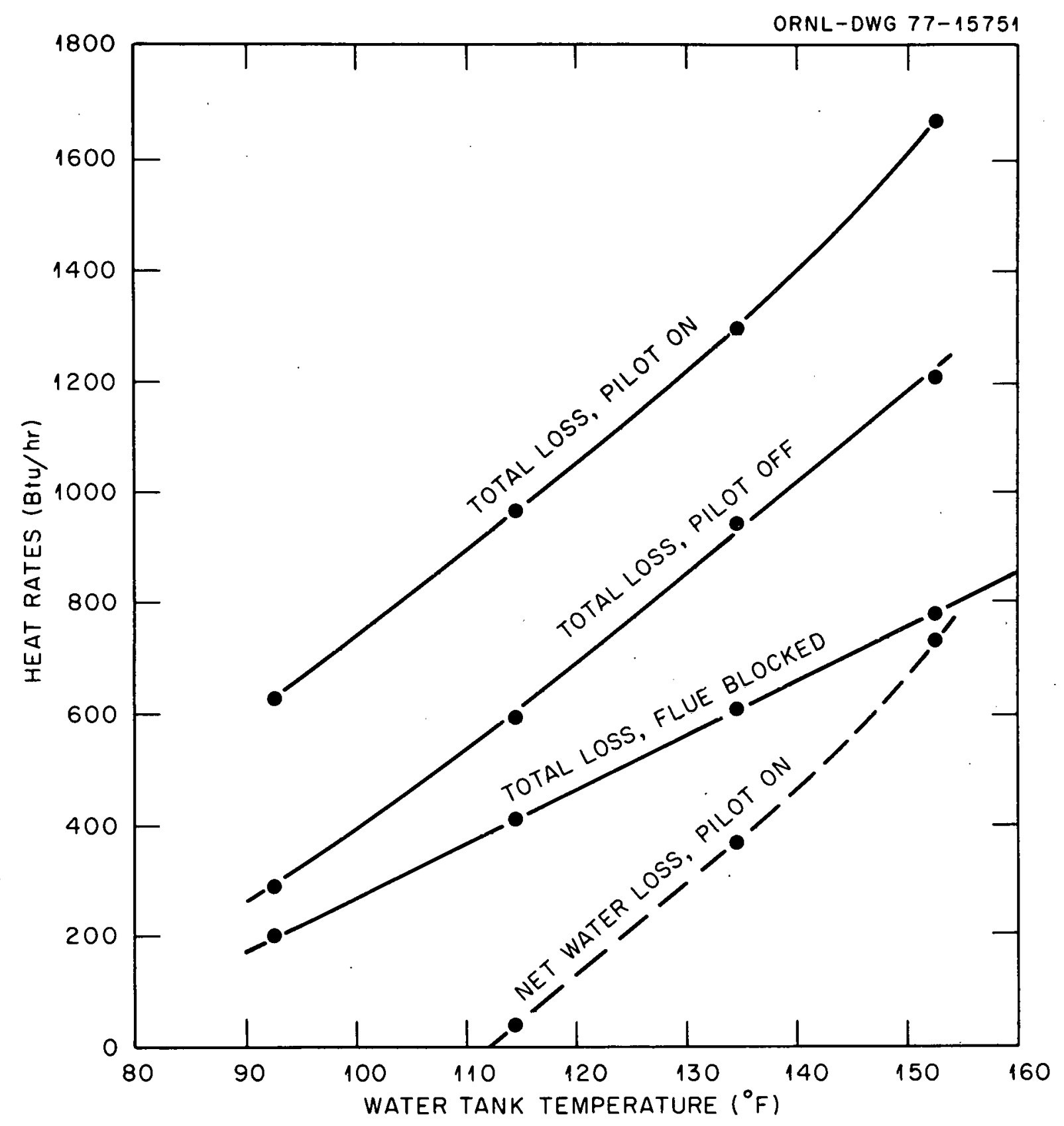

Fig. 4. Gas-fired water heater: tutal heat loss rates vs water tank temperature for three operational configurations. 
$924 \mathrm{Btu} / \mathrm{hr}(271 \mathrm{~W})$, but the water is still falling in temperature. These results for the standby condition are shown in Table 3, together with the calculated total gas consumption required to maintain the water. temperature assuming a main-burner heat-exchange efficiency of $73 \%$.

Table 3. Heat loss rates and gas consumption during standby of gas-fired water heaters

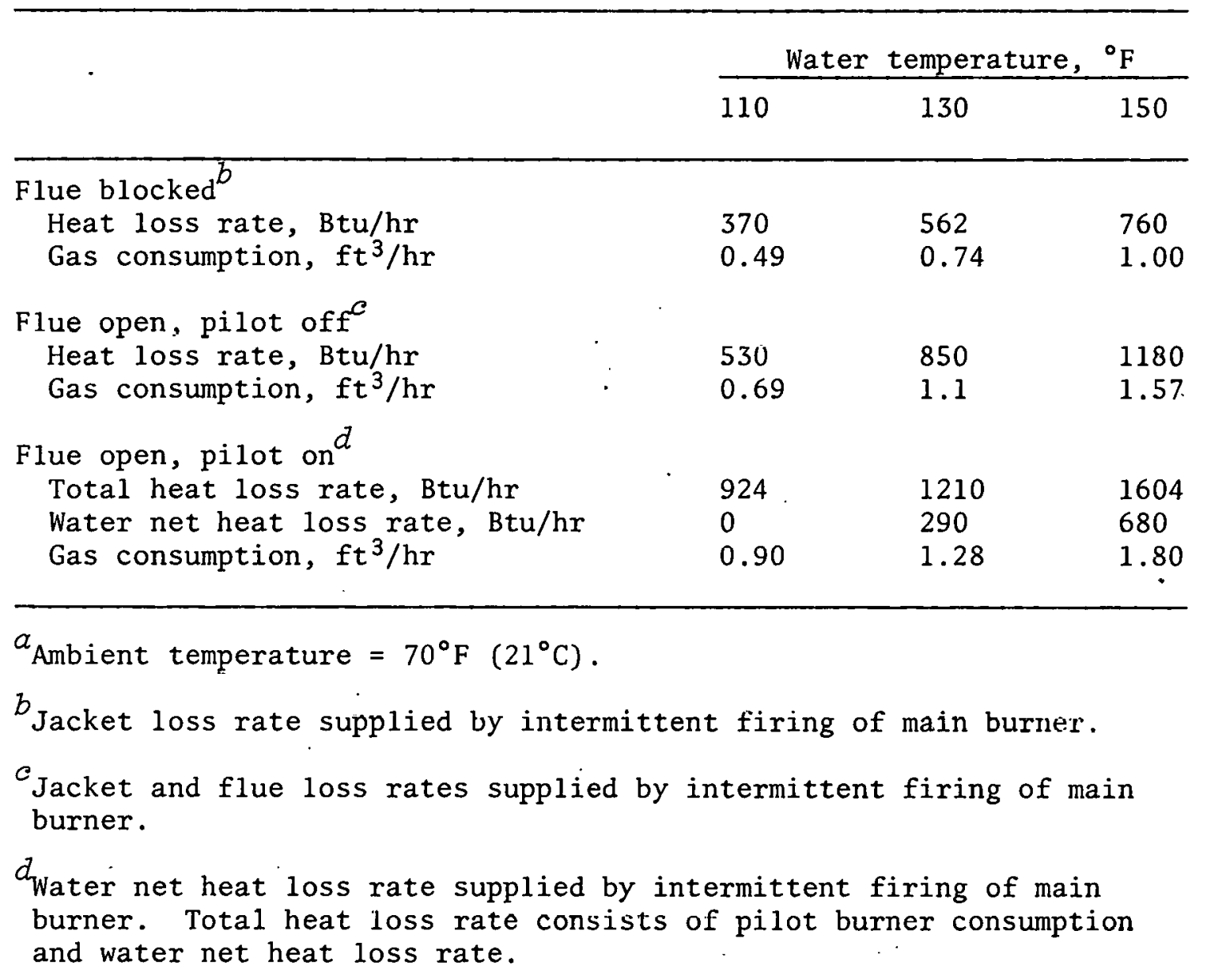

The water heater has now been completely characterized for the cases of the pilot off and flue blocked, and flue unblocked and pilot off and on. The remaining characterization is for the case of the main burner on. This measurement is easy to do by the rate-of-temperaturerise method because the temperature-rise rates are high and are readily 
measured. The parameter measured is termed overall thermodynamic efficiency, or service efficiency. It is given by

[(input heat rate) - (total heat loss rate)]/(input heat rate),

which, in this case, translates into

[(input heat rate) - (flue heat loss rate)

- (jacket heat loss rate)]/(input heat rate).

The results of the measurement are shown in Fig. 5 and also in Table 1. The service efficiency decreases with increasing water temperature because the heat loss through the jacket increases, and there will be a lower temperature difference between the hot flue gases and the water tank to drive heat exchange between the two. Another possible factor, flue gas velocity, seems to be almost independent of water tank temperature as long as the main burner is on. Table 1 also shows the maximum load in gallons per hour that the heater can heat from a ground water input temperature of $55^{\circ} \mathrm{F}\left(12.8^{\circ} \mathrm{C}\right)$. Gas-fired water heaters, in general, have a relatively high recovery rate compared with electric water heaters, because the input heat rate is much higher.

There is considerable room for improvement of the heat-exchange rate between the flue gases and the water tank, since the flue gases exit at a temperature of about $550^{\circ} \mathrm{F}\left(288^{\circ} \mathrm{C}\right)$.

For the main burner, although the water formed by the combustion of the fuel raises the dew point of the flue gases from $43.5^{\circ} \mathrm{F}\left(6.4^{\circ} \mathrm{C}\right)$ entering to $127^{\circ} \mathrm{F}\left(52.8^{\circ} \mathrm{C}\right)$ exiting, the latent heat of vaporization will not be recovered.

It should be evident from these data that efficiencies and heat-exchange rates vary with water tank temperature; for the pilot only, the variation is drastic. Any statement of efficiency of heat-exchange rate should specify the water tank temperature at which the measurement is made, and this temperature should fall within the bounds of reasonable hot-water temperatures $\left[110\right.$ to about $190^{\circ} \mathrm{F}\left(43.3\right.$ to about $\left.\left.87.8^{\circ} \mathrm{C}\right)\right]$. 


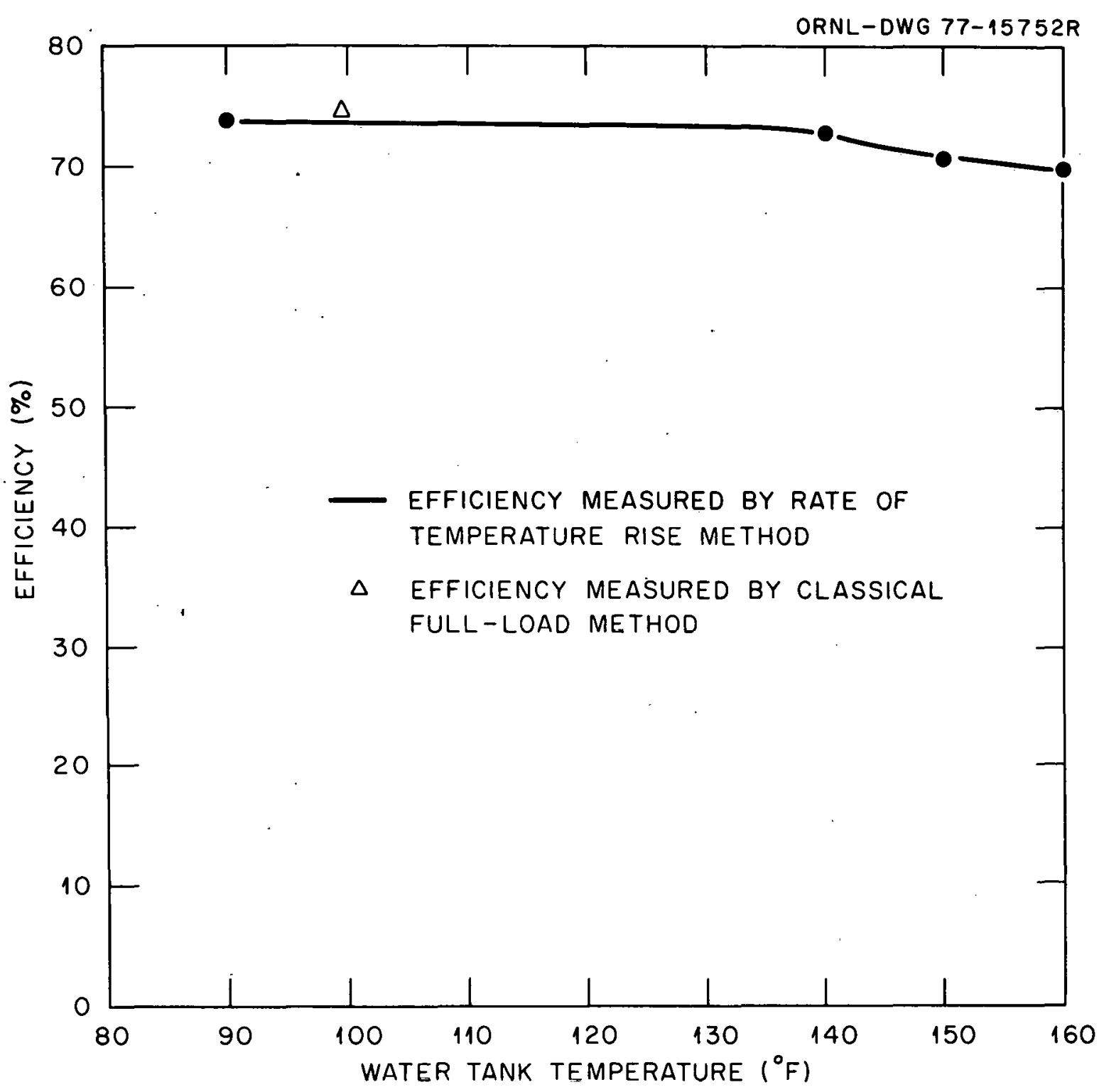

Fig. 5. Gas-fired water heater: service efficiency of main burner vs water tank temperature. 
The efficiency of the heater was measured by the classical method of flowing water through the heater and measuring the temperature rise and flow rate. This method tends to measure the efficiency at an unrealistically low water tank temperature, although it need not do so. The value of $74.8 \%$ service efficiency at an average water tank temperature of $99.5^{\circ} \mathrm{F}\left(37.5^{\circ} \mathrm{C}\right)$ is in agreement with the measurement by rate-oftemperature-rise, but it is misleading to state that the service efficiency of this water heater is $74.8 \%$ without further qualification.

\subsubsection{Further modifications to improve efficiency and energy conservation}

In the previous section, two modifications were suggested following the measurement of the characteristics of gas-fired water heaters in the standhy mode - flue blocking in the standby mode and electric ignition. Both of these eliminate the standing pilot burner, which is energyinefficient. If both of these are invoked, then the standby heat loss rate is essentially the jacket heat loss rate. This can be reduced by (1) the addition of extra insulation internal to the jacket, which is feasible only at the time of manufacture; or (2) retrofit of additional insulation outside the jacket. For safety reasons, neither of these modifications should be attempted by the homeowner. Carbon monoxide production and explosion could be the result of improperly executed modifications. The gas-fired water heater was retrofitted in the laboratory by wrapping it with 3 1/2-in.-thick $(8.9-\mathrm{cm}), \mathrm{R}-11$ glass fiber building insulation, with the joints taped. The jacket heat loss rates for both the retrofit configuration and the as-received configuration are shown in Fig. 6 and in Table 4 as a function of water temperature. At a water temperature of $150^{\circ} \mathrm{F}\left(65.6^{\circ} \mathrm{C}\right)$, the extra insulation reduces the jacket heat loss rate to $40 \%$ of that without the extra insulation.

The pilot burner is an energy waster because it is operating under hi.ghly diluted combustion conditions. If the pilot could be made to operate at a fuel-air ratio nearer to stoichiometric, the heat transfer efficiency would increase and would not fall off so rapidly with increasing water temperature. The tremendous advantage of the standing 


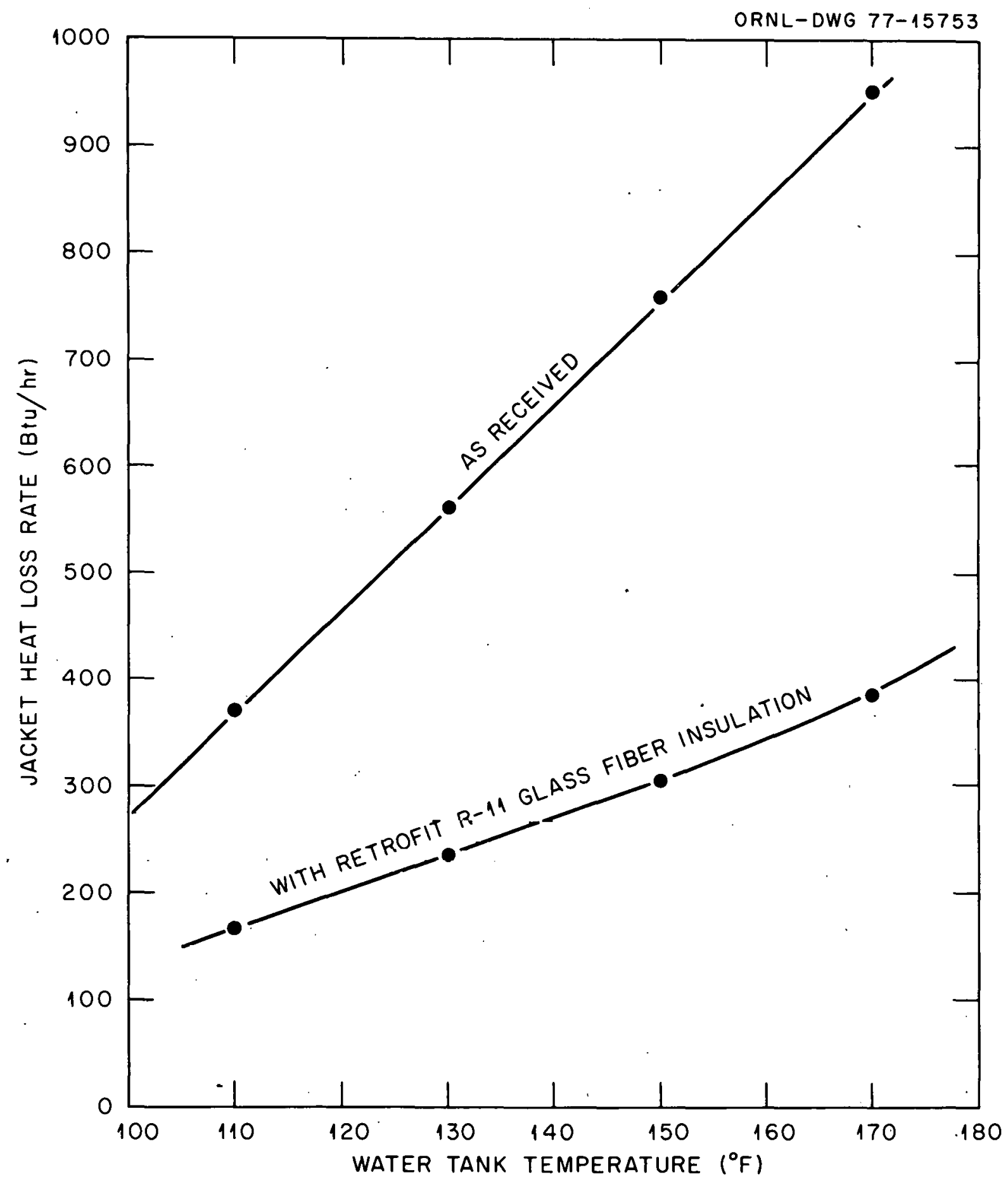

Fig. 6. Jacket heat loss rates for gas-fired water heater, as received and with retrofit insulation. 
Table 4. Jacket heat loss rate for a

50-gal gas-fired water heater ${ }^{\alpha}$

\begin{tabular}{ccc}
\hline & & Jacket heat loss rate, Btu/hr \\
\cline { 2 - 3 } $\begin{array}{c}\text { Water temperature } \\
\left({ }^{\circ} \mathrm{F}\right)\end{array}$ & As received & $\begin{array}{c}\text { Retrofitted with } \\
3 \text { 1/2-in. R-11 } \\
\text { insulation }\end{array}$ \\
\hline 110 & 370 & 166 \\
130 & 562 & 234 \\
150 & 760 & 304 \\
170 & 955 & 386 \\
\hline
\end{tabular}

$a_{\text {Ambient temperature }}=70^{\circ} \mathrm{F}$, measured with pilot light off and flue blocked.

pilot as a constant source of ignition for the main burner would be retained. This was done in the laboratory by restricting the stack orifice to approximately one-fiftieth of the original area. Of course, the main burner was not allowed to operate with the orifice restriction in place. The heat-exchange efficiency as a function of water temperature with this modification is shown in Table 5 . With the orifice restriction and the R-11 retrofitted insulation, the water reached an asymptotic

Table 5. Pilot heat-transfer efficiency for gas-fired water heater with stack restricted by $5 / 16-i n$. orifice

Tank temperature

$\left({ }^{\circ} \mathrm{F}\right)$
Heat-transfer efficiency (\%)

77.6

140

75.5

160

$71: 0$

170

69.0

180

64.0

186

53.0 
temperature (heat-exchange rate balanced by jacket heat loss rate) of $186^{\circ} \mathrm{F}\left(85.6^{\circ} \mathrm{C}\right)$. If the heat-exchange efficiency is interpolated to be $72 \%$ (Table 5) with this configuration at a water temperature of $150^{\circ} \mathrm{F}$ $\left(65.6^{\circ} \mathrm{C}\right)$, then the jacket heat loss rate of $304 \mathrm{Btu} / \mathrm{hr}(89 \mathrm{~W})$ would be balanced by a pilot heat input of $442 \mathrm{Btu} / \mathrm{hr}(129 \mathrm{~W})$, or $0.41 \mathrm{ft}^{3} / \mathrm{hr}$ $\left(1.16 \times 10^{-2} \mathrm{~m}^{3} / \mathrm{hr}\right.$ ) (with further orifice restriction to maintain a proper excess-air ratio). This would be the total energy loss rate, since the water tank is neither increasing nor decreasing in temperature.

The replacement of the restricted-orifice pilot with standby flue blocking and electric ignition would decrease the total energy loss rate to 304 $\mathrm{Btu} / \mathrm{hr}$, which hardly seems worth the trouble and expense. It would be highly advantageous if such a flue restriction could be applied and removed without the benefit of electrical service. Large quantities of heat energy are available when the main burner is firing, and it should be possible to transform some of this thermal energy to mechanical energy for removing an orifice restriction.

\section{1 .4 Power burner tests}

Power gas burners with a standing pilot light are commercially available for use in gas furnace applications. One of these was rejetted to $33,700 \mathrm{Btu} / \mathrm{hr}(9876 \mathrm{~W})$ and installed in the 50-gal $\left(0.1893-\mathrm{m}^{3}\right)$ gasfired water heater. The base of the water heater was sealed so that combustion air could enter only through the blower intake. The air passages were sized so that the pilot operated with a reasonable excessair ratio, and the additional air required for main burner consumption was supplied by the blower. A centrifugal switch on the blower motor opens an electric main gas valve only after the blower is up to speed. A disk-and-doughnut baffle array was installed in the flue, and the pilot gas flow was reduced to $0.56 \mathrm{ft}^{3} / \mathrm{hr}\left(1.59 \times 10^{-2} \mathrm{~m}^{3} / \mathrm{hr}\right)$, or 577 $\mathrm{Btu} / \mathrm{hr}(169 \mathrm{~W})$. The heater was equipped with the $\mathrm{R}-11$ retrofit insulation for this test.

The water heater equipped with the power gas burner was not completely characterized as a function of water temperature, but some significant measurements were made of its performance. Referred to a 
$70^{\circ} \mathrm{F}\left(21.1^{\circ} \mathrm{C}\right)$ ambient, the asymptotic water tank temperature attained with only the pilot burning was $143^{\circ} \mathrm{F}\left(61.7^{\circ} \mathrm{C}\right)$. The jacket heat loss rate at this temperature, which exactly balances the heat input from the flue gas, is $280 \mathrm{Btu} / \mathrm{hr}(82 \mathrm{~W})$, so the heat-exchange efficiency of the pilot burner at this temperature is $280 / 577$, or $49 \%$; and the total energy-loss rate is the input heat rate of $577 \mathrm{Btu} / \mathrm{hr}(169 \mathrm{~W})$. The flue gas exit temperature without the disk-and-doughnut baffle array was $460^{\circ} \mathrm{F}\left(238^{\circ} \mathrm{C}\right)$ with the main burner on. The combination of the baffle and the power burner provided a dramatic improvement in main burner performance. At a water temperature of $160^{\circ} \mathrm{F}\left(71.1^{\circ} \mathrm{C}\right)$, the main burner heat-exchange efficiency was increased to about $85 \%$ (compared to $72 \%$ without the power burner), the excess-air ratio was 1.31 , and the flue gas exit temperature was only $255^{\circ} \mathrm{F}\left(124^{\circ} \mathrm{C}\right)$. The implications of these improvements will be discussed in Sect. 4 .

\subsection{Electric Water Heaters}

\subsubsection{Description}

The electric water heater tested in the laboratory was a fast-recovery type with a 66-gal $\left(0.25-\mathrm{m}^{3}\right)$ nominal capacity. As shown in Fig. 7 , the details of the tank, insulation, jacket, and water connections are similar to the gas-fired water heater. The tank is $20 \mathrm{in.}(50.8 \mathrm{~cm})$ in diameter and 48.5 in. $(123 \mathrm{~cm})$ tall. Two inches $(5.1 \mathrm{~cm})$ of glass fiber insulation separate the tank wall and the outer jacket. Totāl-immersion heaters of $4500 \mathrm{~W}$ nominal rating each are located near the top and bottom of the heater. Thermostats near the top and bottom of the heater control the heating elements to prevent simultaneous operation. They are usually set for the same temperature. If the top thermostat is calling for water heating, the top element is powered; convection currents in the water causc the water between the heating element and the outlet to be heated. When the top thermostat is satisfied, the thermostat transfers the electrical power to the bottom thermostat, which powers the bottom heater. Convection currents cause the water between the lower element and the tonp of the tank to be heated. When the lower thermustat is 


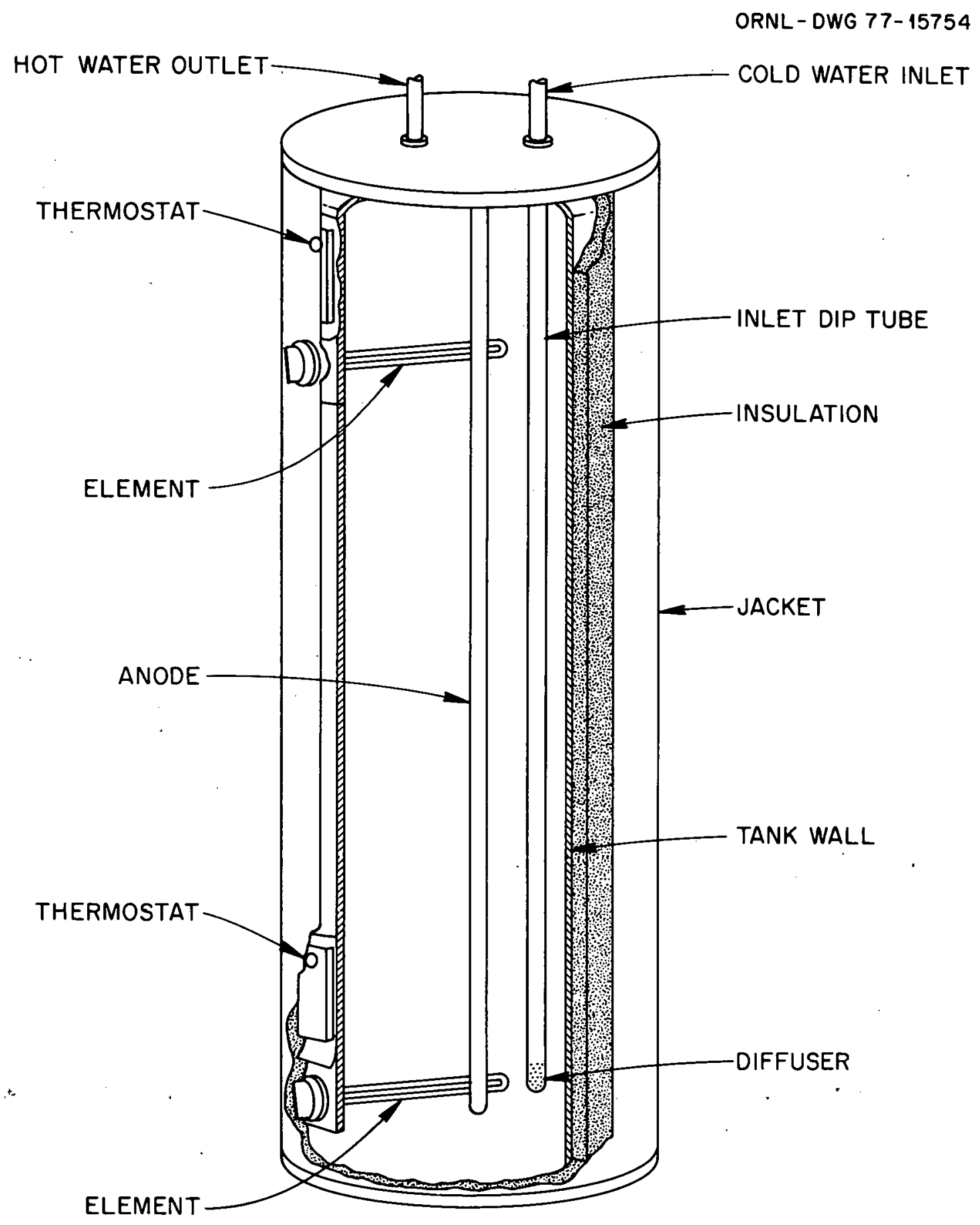

Fig. 7. Fast-recovery-type 66-gal electric water heater. 
satisfied, both heaters are off. If the heater is recovering after having been totally drained of hot water, this arrangement allows a small volume of water at the top of the heater to be heated quickly, rather than waiting for the lower heater to heat the whole tank.

A 30-gal $\left(0.1136-\mathrm{m}^{3}\right), 2000-W$ mobile-home water heater was also tested in the laboratory. The dimensions of the tank are $16.6 \mathrm{in.}(42.2$ $\mathrm{cm})$ in diameter by $32 \mathrm{in.}(81.3 \mathrm{~cm}) \mathrm{high}$, and $3 / 4$ in. $(1.9 \mathrm{~cm})$ of glass fiber insulation separates the tank and the outer jacket. Unless otherwise stated, the following remarks will refer to the 66-gal $\left(0.25-\mathrm{m}^{3}\right)$ electric water heater.

A critical look at the design of the 66 -gal $\left(0.25-\mathrm{m}^{3}\right)$ electric water heater indicates that the jacket loss per unit area of tank will be less for the same ambient temperature than that of the gas-fired water heater, because the insulation is thicker. 'l'he heat-exchange efficiency should be close to $100 \%$, since the heaters are totally immersed in the water. The recovery rate of the electric heater should be lower than for the gas heater, since the heat-exchange rate is nominally $15,350 \mathrm{Btu} / \mathrm{hr}$. $(4500 \mathrm{~W})$ as compared with the gas water heater exchange rate of about $33,500 \mathrm{Btu} / \mathrm{hr}(9818 \mathrm{~W})$. The rate of temperature rise during recovery will be less than the factor indicated by the heat-exchange input heat rates, since the electric water heater tank is larger. The power input rate to the electric water heater elements was measured as $4200 \mathrm{~W}$ $(14,330 \mathrm{Btu} / \mathrm{hr})$ instead of the nominal rating of $4500 \mathrm{~W}$.

\subsubsection{Characterization of electric water heaters}

The heat input rate from the elements, and the jacket and piping heat loss rates as a function of temperature, completely characterize the electric water heater. The jacket heat loss rate was measured (as for the gas-fired water heater) by the temperature-rate-of-decay method. The service efficiency is then:

[(heat input rate) - (jacket heat loss rate)]/(heat input rate) . 
These heat loss rates are shown in Fig. 8 and in Table 6 for various insulation configurations and water temperatures. Note that at $150^{\circ} \mathrm{F}$ $\left(65.6^{\circ} \mathrm{C}\right)$, the retrofit $\mathrm{R}-11$ insulation reduces the heat loss rate to $68 \%$ of that without the extra insulation, as compared with $40 \%$ of the heat loss rate without extra insulation for the gas-fired water heater. The electric water heater is equipped with more insulation at the factory, so the reduction in heat loss is less with the addition of extra insulation. Table 7 shows the service efficiency and recovery rate $\left[55^{\circ} \mathrm{F}\right.$ $\left(12.8^{\circ} \mathrm{C}\right)$ in] for both electric water heaters in the as-received insulation configuration. The 66-gal $\left(0.25-\mathrm{m}^{3}\right)$ electric water heater has a much lower maximum load or recovery rate than the gas-fired water heater and a higher service efficiency than the 30-gal $\left(0.1136-\mathrm{m}^{3}\right)$ electric water heater. The $8-\mathrm{gal} / \mathrm{hr}\left(0.03-\mathrm{m}^{3} / \mathrm{hr}\right)$ recovery rate of the mobile-home $30-\mathrm{gal}$ $\left(0.1136-\mathrm{m}^{3}\right)$ water heater is marginal for many family use patterns.

These efficiencies are quite high if the heat input rate from the power lines is considered. However, the overall efficiency of the electric power generation and distribution system is about $29 \%$, so the above efficiencies must be multiplied by 0.29 to obtain the ratio (useful heat rate)/(heat rate input at power station). This latter ratio is significant in regard to conservation of energy resources. Historically, the cost of heat trom the direcl cumbustion of fossil fuels has heen sonsiderably lower than the cost from electric resistive heat, which may explain the rationale for the thicker insulation layer on the electric water heater.

\subsection{Efficiency Evaluation of Water Heaters: Appliance} Efficiency and Service Efficiency

The so-called appliance efficiency of a water heater credits the heater with a fixed useful output of hot water [for example, 75 gal heated from 55 to $150^{\circ} \mathrm{F}\left(12.8\right.$ to $\left.65.6^{\circ} \mathrm{C}\right)$ ] during a fixed time period for example, 24 hours - and charges the heater with both the useful output and the total energy losses for the full period. In general, the heater is capable of producing the useful output in a small fraction of the fixed time period. The appliance efficiency is thereby distinguished from the instantaneous, or service, efficiency in that the heater is 


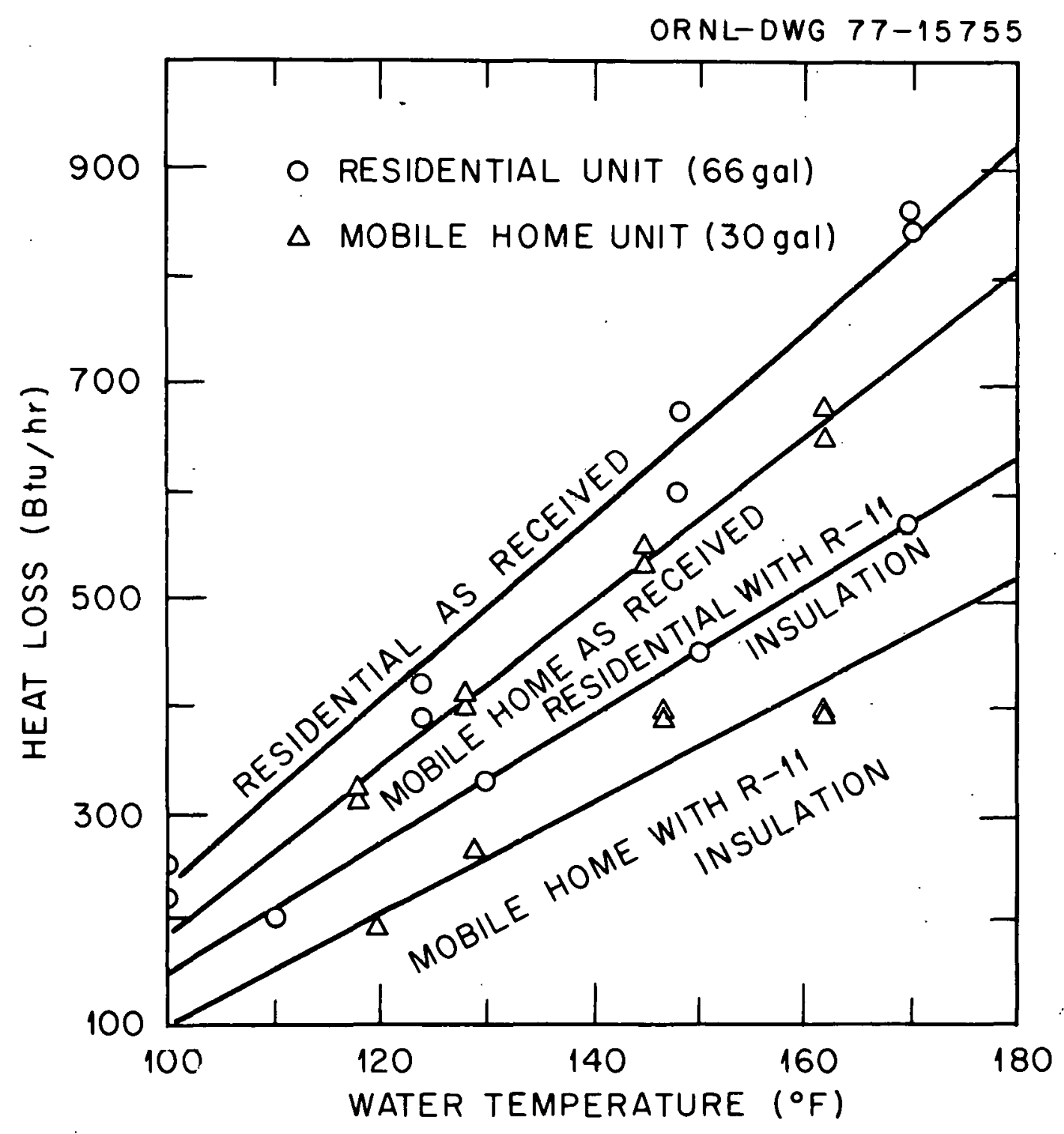

Fig. 8. Standby heat loss rates for electric water heaters vs water temperature with typical data points shown (ambient temperature $=70^{\circ} \mathrm{F}$ ). 
Table 6. Standby heat losses of electric water heaters ${ }^{a}$

\begin{tabular}{|c|c|c|c|c|c|}
\hline \multirow[b]{3}{*}{$\begin{array}{l}\text { Water temp. } \\
\left({ }^{\circ} \mathrm{F}\right)\end{array}$} & \multicolumn{5}{|c|}{ Standby heat loss, Btu/hr } \\
\hline & \multicolumn{3}{|c|}{ 66-gal residential } & \multicolumn{2}{|c|}{ 30-gal mobile home } \\
\hline & $\begin{array}{l}\text { As received } \\
(2-i n . \text { ins.) }\end{array}$ & $\begin{array}{l}11 / 2-i n . \text { kit } \\
\text { retrofitted }\end{array}$ & $\begin{array}{l}31 / 2-\text { in. } R-11 \\
\text { retrofitted }\end{array}$ & $\begin{array}{c}\text { As received } \\
(3 / 4-i n . \text { ins.) }\end{array}$ & $\begin{array}{l}31 / 2-i n . R-11 \\
\text { retrofitted }\end{array}$ \\
\hline 110 & 315 & 227 & 206 & 265 & 151 \\
\hline 130 & 487 & 351 & 325 & 420 & 256 \\
\hline 150 & 660 & 482 & 446 & 577 & 360 \\
\hline 170 & 832 & 610 & 569 & 731 & 477 \\
\hline
\end{tabular}

$a_{\text {Ambient temperature }}=70^{\circ} \mathrm{F}$. 
Table 7. Full-load efficiency of 30- and 66-gal electric water heaters $\left(55^{\circ} \mathrm{F}\right.$ input temperature)

\begin{tabular}{|c|c|c|c|}
\hline Water & $\begin{array}{l}\text { temperature } \\
\left({ }^{\circ} \mathrm{F}\right)\end{array}$ & $\begin{array}{l}\text { Maximum load } \\
\text { (gal/hr) }\end{array}$ & $\begin{array}{l}\text { Service efficiency } \\
(\%)\end{array}$ \\
\hline \multicolumn{4}{|c|}{ 30-gal tank } \\
\hline & 110 & 14.4 & 96 \\
\hline & 130 & 10.4 & 94 \\
\hline \multirow{2}{*}{\multicolumn{2}{|c|}{150}} & 8.0 & 92 \\
\hline & & 66-gal tank & \\
\hline & 110 & 30.8 & 97.8 \\
\hline & .130 & 22.43 & 96.6 \\
\hline & 150 & 17.6 & 95.4 \\
\hline
\end{tabular}

charged with the energy loss during standby conditions for long periods of time. The indirect consumptions of the heater, such as for air conditioning the combustion air or removing heat leaking through the jacket, are not considered in the definitions of either efficiency. The definition of appliance efficiency brings up conceptual questions regarding its calculation. Since the heat loss rate of a water heater is dependent upon the water temperature, appropriate temperatures must be used for both the standby phase and the water heating phase of the daily operation. Also, the specification of a fixed output affects the efficiency of large versus small heaters. The suitable water temperatures for the two phases of heater operation will be considered first.

The concepts involved will be explained in terms of electric water heaters; specifically, the 66-gal $\left(0.25-\mathrm{m}^{3}\right)$ heater. The heat loss rate of a heater is almost directly proportional to the difference between the water temperature and the ambient temperature within the temperature range of interest. This implies that the time rate of decay of the heater temperature without any heat input is closely exponential with time. If the temperature is allowed to decay a small fraction of the 
temperature difference between the nominal thermostat set point and the ambient temperature, then the decay can be considered to be almost linear, and average temperatures can be used with little error. While the main heat source is on, the exponential term is overwhelmed by it, and again the average temperatures can be used with little error. If the hysteresis of the thermostat is centered on $150^{\circ} \mathrm{F}\left(65.6^{\circ} \mathrm{C}\right)$, then the time average of the tank temperature will be very close to $150^{\circ} \mathrm{F}$ $\left(65.6^{\circ} \mathrm{C}\right)$, and the appropriate heat loss rate will be $660 \mathrm{Btu} / \mathrm{hr}(193 \mathrm{~W})$ (from Table 6) during standby, if the thermostat hysteresis is not too large. If $75 \mathrm{gal} / \mathrm{day}\left(0.28 \mathrm{~m}^{3} / \mathrm{day}\right)$ of hot water is drawn at a constant rate of $3.125 \mathrm{gal} / \mathrm{hr}\left(0.012 \mathrm{~m}^{3} / \mathrm{hr}\right)$, then the influx of water at $55^{\circ} \mathrm{F}$ $\left(12.8^{\circ} \mathrm{C}\right)$ will reduce the heat content of the stored water by $2451 \mathrm{Btu} / \mathrm{hr}$ $(718 \mathrm{~W})$, in addition to the $660 \mathrm{Btu} / \mathrm{hr}$ (193 W) lost through the jacket. This total loss rate is well within the $14,330 \mathrm{Btu} / \mathrm{hr}(4200 \mathrm{~W})$ capacity of the main heating element, so the water temperature will stay within the thermostat dead band, the average will again be $150^{\circ} \mathrm{F}\left(65.6^{\circ} \mathrm{C}\right)$, and the average jacket heat loss will be $660 \mathrm{Btu} / \mathrm{hr}$ (193 W) during the recovery phase, or a total of $15,840 \mathrm{Btu} /$ day (1672 $\mathrm{MJ} /$ day).

Assume that the water is delivered in two sudden draws of 37.5 gal $\left(0.14 \mathrm{~m}^{3}\right)$ each, with time between draws for complete recovery of the heater. 'The stratification within the hedLer is such lliat the output will be very close to the assumed temperature of $150^{\circ} \mathrm{F}\left(65.6^{\circ} \mathrm{C}\right)$ even at the end of the draw. The influx of cold water reduces the temperature of the tank to $96^{\circ} \mathrm{F}\left(35.6^{\circ} \mathrm{C}\right)$, so that the average temperature during water heating is the average of the thermostat set point and this temperature, or $123^{\circ} \mathrm{F}\left(50.6^{\circ} \mathrm{C}\right)$. The average heat loss rate during this period would be about $430 \mathrm{Btu} / \mathrm{hr}(126 \mathrm{~W})$. The actual draw schedule will probably be between the two extremes of slow draw and fast draw cited above, and the appropriate average temperature during water heating would be between 123 and $150^{\circ} \mathrm{F}\left(50.6\right.$ and $\left.65.6^{\circ} \mathrm{C}\right)$.

It is common practice to assume that the recovery efficiency, $E_{r}$, applies in all cases of water heater recovery regardless of the draw schedule. The recovery efficiency would be measured for the 66-gal $\left(0.25-\mathrm{m}^{3}\right)$ electric water heater under the above-assumed conditions by filling the heater with water at $55^{\circ} \mathrm{F}\left(12.8^{\circ} \mathrm{C}\right)$ and measuring the total 
input energy required to raise the water temperature to $150^{\circ} \mathrm{F}\left(65.6^{\circ} \mathrm{C}\right)$. The recovery efficiency would then be the quotient of the heat added to the water and the total heat input to the heater during the period. The recovery efficiency includes the initial heating period during which the efficiency is greater than $100 \%$ because heat flows into the water [initially at $55^{\circ} \mathrm{F}\left(12.8^{\circ} \mathrm{C}\right)$ ] from the surroundings at $70^{\circ} \mathrm{F}\left(21.1^{\circ} \mathrm{C}\right)$. The effective average temperature during the recovery efficiency measurement is very close to the average of the starting and ending temperatures of the water, or $102.5^{\circ} \mathrm{F}\left(39.2^{\circ} \mathrm{C}\right)$. This is not a suitable temperature to use for calculating the heat loss rate through the jacket during the water heating phase. The difference in using the recovery efficiency and the actual heat loss rates is not large, so the error is more conceptual than actual. The heat loss rate at the thermostat set point will be used for appliance efficiency calculations as being more representative of the true situation.

Since the appliance efficiency is defined as the quotient of a fixed useful output and the sum of the useful output and the total losses for the stated period, it is obvious that the appliance efficiency can be increased by reducing the total losses. This may be done for an electric water heater by increasing the thickness and $R$ value of the insulation or by reducing the size of the tank, using the same insulation configuration. The heat loss rate through the jacket of a heater with a given thickness and $R$ value of insulation is closely proportional, for a given shape, to the area of the bare tank which in turn is proportional to $\mathrm{V}^{2 / 3}$, where $V$ is the volume of the tank. Stated mathematically, then,

appliance efficiency $=$ useful output $/$ (useful output $+C_{2} V^{2 / 3}$ ),

where $C_{2}$ is the appropriate dimensioned constant to relate the surface area of the tank and the energy loss rate through the jacket. For a given $C_{2}$ (shape of tank, insulation thickness, and $R$ value fixed), the appliance efficiency decreases monotonically with an increase in $V$. Thus an appliance which is not in conformity with a stated appliance efficiency criterion could be brought into conformance merely by reducing the size of the tank. 
The original criterion for the performance of gas-fired water heaters in delivering a quota of hot water per day specified that the quota vary essentially as $\mathrm{V}^{2 / 3}$, or the uninsulated tank area. ${ }^{3}$ With this specified variation, the expression for appliance efficiency becomes:

$$
\text { appliance efficiency }=\mathrm{C}_{1} \mathrm{~V}^{2 / 3} /\left(\mathrm{C}_{1} \mathrm{~V}^{2 / 3}+\mathrm{C}_{2} \mathrm{~V}^{2 / 3}\right) \text {, }
$$

where $C_{l}$ is the dimensioned constant which relates the calculated heat output in the form of hot water and the surface area of the tank. This expression is obviously independent of the volume of the heater.

Service efficiency, previously defined, gives very little information regarding the performance of an electric water heater other than the relative magnitudes of the jacket heat loss rate and the input heat rate. This efficiency may be raised by increasing the wattage of the heating element, which has no effect upon the energy-conserving aspects of the performance; or by applying better insulation. Main heater elements in domestic electric water heaters seem to be limited to $4500 \mathrm{~W}$ (nonsimultaneous operation is usually specified for heaters with two heating elements), so a stated service efficiency would discriminate against large electric heaters.

The calculaled applialle efficiencies for the two clcctric wator heaters tested are shown in Fig. 9 for two water temperatures. The jacket heat loss rates appropriate to the temperatures shown on the figure were used. The large heater had a greater thickness of insulation surrounding it, with a concomitantly lower heat loss rate per unit of tank area. However, the total heat loss rate of the large heater is larger, so it has a lower appliance efficiency than the poorly insulated mobile-home heater. This is an example of the size effect on appliance efficiency.

Domestic hot water requirements vary widely. Households that require large amounts of hot water each day should have a correspondingly large water heater. From an energy conserving point of view, it is generally not advisable to substitute several small water heaters for one large one, even though both definitions of efficiency might suggest otherwise. 


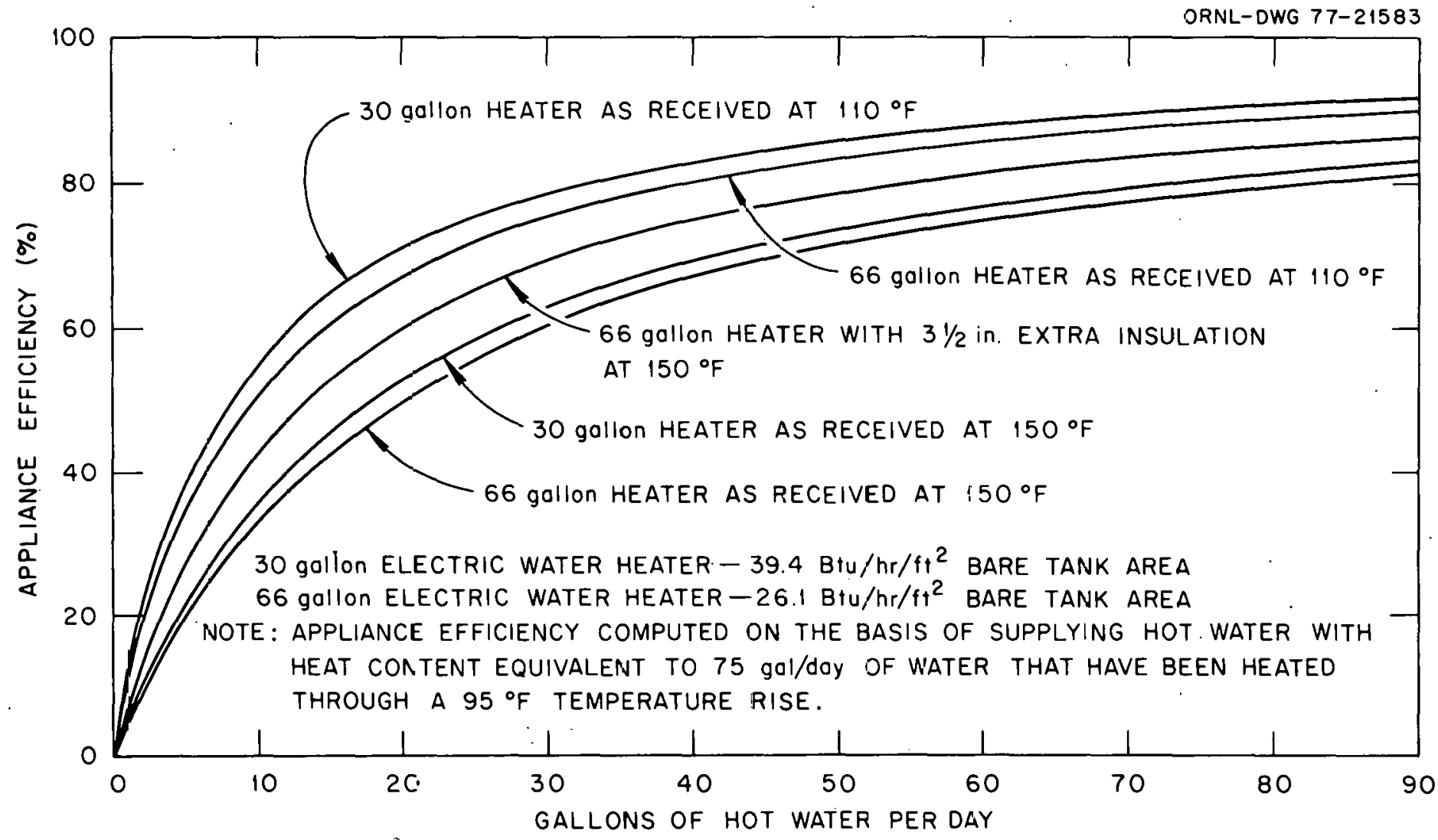

Fig. 9: Appliance efficiencies of electric water heaters. 
For example, if we consider the two electric water heaters we have tested, we have already noted that the 30 -gal $\left(0.1136-\mathrm{m}^{3}\right)$ water heater has a higher appliance efficiency than the 66-gal $\left(0.25-\mathrm{m}^{3}\right)$ heater even though the smaller heater has less insulation. From Table 6 we see that at $150^{\circ} \mathrm{F}\left(66^{\circ} \mathrm{C}\right)$ the $66-$ gal $\left(0.25-\mathrm{m}^{3}\right)$ water heater has a standby heat loss of $660 \mathrm{Btu} / \mathrm{hr}(193 \mathrm{~W})$ whereas two 30 -gal $\left(0.1136-\mathrm{m}^{3}\right)$ water heaters would have a total heat loss of $1150 \mathrm{Btu} / \mathrm{hr}(337 \mathrm{~W})$. Even with retrofitted insulation of $31 / 2 \mathrm{in.}(88.9 \mathrm{~mm})$ on each tank the loss rate is $446 \mathrm{Btu} / \mathrm{hr}(131 \mathrm{~W})$ for the $66-\mathrm{gal}\left(0.25-\mathrm{m}^{3}\right)$ tank versus $720 \mathrm{Btu} / \mathrm{hr}(211 \mathrm{~W})$ for two $30-\mathrm{gal}\left(0.1136-\mathrm{m}^{3}\right)$ water heaters.

The calculation of the appliance efficiency for the gas-fired water heater is not as straightforward as for the electric water heaters because the jacket loss is supplied at a higher heat-exchange efficiency while the main burner is on. The appliance efficiency curves shown in Fig. 10 are for the as-received configuration and the retrofit insulation with flue-blocked configuration. At $150^{\circ} \mathrm{F}\left(65.6^{\circ} \mathrm{C}\right)$, the modification increases the appliance efficiency for delivery of $75 \mathrm{gal}\left(0.28 \mathrm{~m}^{3}\right)$ of water per day from 0.48 to 0.65 .

Appliance efficiency and service efficiency are essentially responsive to the total heat loss rate of a heater, thereby favoring small heaters. If, instead, one wishes to specify a criterion that is independent of both size and throughput, then the jacket heat loss rate per unit of bare tank area should be used. For both electric and gas-fired water heaters, this quantity is a good measure of insulation quality.

Gas-fired water heaters suffer flue losses in addition to jacket losses. There is considerable potential for reduction of flue heat loss rates in gas-fired water heaters. For the 50 -gal $\left(0.189-\mathrm{m}^{3}\right)$ gasfired water heater in the as-received configuration at a water temperature of $160^{\circ} \mathrm{F}\left(71.1^{\circ} \mathrm{C}\right)$, the main burner flue losses approached $28 \%$ and the flue gas exited at a temperature of $550^{\circ} \mathrm{F}\left(288^{\circ} \mathrm{C}\right)$. With the power burner modification, the main burner flue losses at the same water temperature were $15 \%$ and the flue gas exited at a temperature of $255^{\circ} \mathrm{F}\left(124^{\circ} \mathrm{C}\right)$. The main burner flue losses probably cannot be reduced much below $15 \%$ because some excess air must be provided to prevent carbon monoxide formation. 


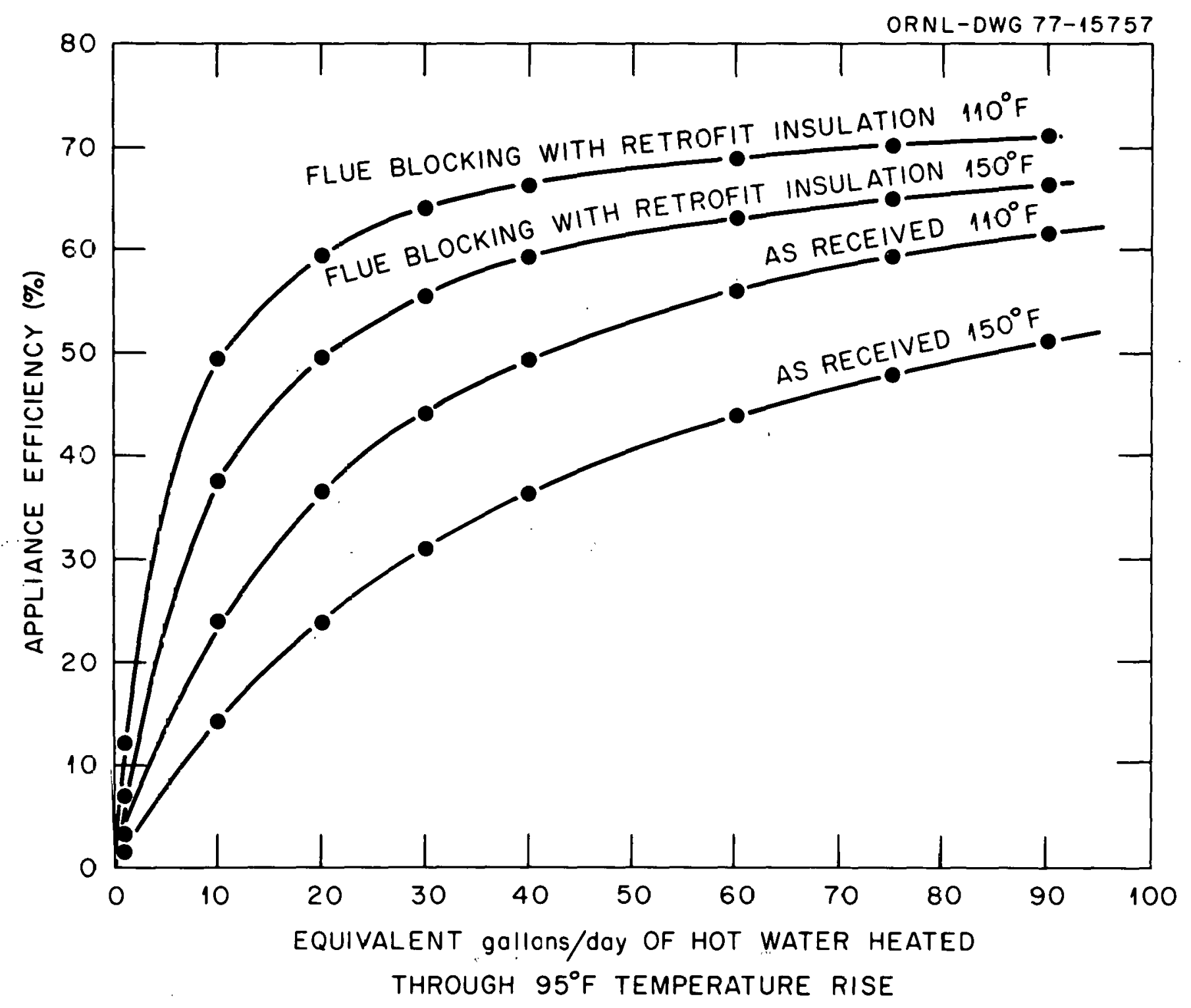

Fig. 10. Appliance efficiency of 50-gal gas-fired water heater. 
The pilot burner flue losses in the as-received configuration were $92 \%$ at an operating temperature of $150^{\circ} \mathrm{F}\left(65.6^{\circ} \mathrm{C}\right)$. This heat loss rate was reduced to about $25 \%$ of the input by means of the flue orifice restriction, and was essentially eliminated by flue blocking with electric ignition.

The power burner pilot has a flue loss rate of $51 \%$ at a tank temperature of $143^{\circ} \mathrm{F}\left(61.7^{\circ} \mathrm{C}\right)$. The air intake orifice had to be adjusted to eliminate carbon monoxide in the main burner flue gas. The orifice could be restricted for pilot operation by a light flapper which is lifted by the blower draft. 


\section{ENERGY CONSERVATION PRACTICES IN THE HOME}

Energy conservation measures undertaken in the home have varying effects upon the lifestyle of the occupants, and this is particularly true of hot water use patterns. For example, a shower or bath at $110^{\circ} \mathrm{F}$ $\left(43.3^{\circ} \mathrm{C}\right)$ is the hottest water that most people can tolerate. The average bath temperature is about $105^{\circ} \mathrm{F}\left(40.6^{\circ} \mathrm{C}\right)$, and a shower at $100^{\circ} \mathrm{F}\left(37.8^{\circ} \mathrm{C}\right)$ would still feel warm. If this were the only criterion, then a water temperature of $110^{\circ} \mathrm{F}\left(43.3^{\circ} \mathrm{C}\right)$ would be satisfactory. The highesttemperature water is demanded by an automatic dishwasher for sanitary reasons. Many automatic dishwashers have auxiliary heaters to heat the water to a higher temperature if necessary, so with those machines, the lower limit on hot-water temperature would not be set by the automatic dishwasher. Dishwäshing by hand is limited to water temperatures that a hand (probably in rubber gloves) can tolerate. The hand-rinse process might set a somewhat higher minimum temperature. Clothes washing involves so many variables, both physical and aesthetic, that no attempt will be made to specify a minimum hot-water temperature for this process.

In consideration of the above uses, the easiest way to save water-heating energy is merely to lower the thermostat setting. The standby heat loss rate is directly responsive to the lowered setting and is almost independent of the amount of water used. The thermostat setting can be lowered if none of the above uses are jeopardized and if the heat content of the stored water is adequate for the use schedule. For example, if a certain volume of water at $105^{\circ} \mathrm{F}\left(40.6^{\circ} \mathrm{C}\right)$ is obtained for a shower by mixing incoming water [at about $55^{\circ} \mathrm{F}\left(12.8^{\circ} \mathrm{C}\right)$ ] and water from the heater, the total heat content of the water used is independent of the thermostat setting as long as it is $105^{\circ} \mathrm{F}\left(40.6^{\circ} \mathrm{C}\right)$ or higher. The heat content of the stored water is directly proportional to the difference between the storage temperature and the temperature of the incoming water and may not be adequate if the thermostat setting is too low. Another means of reducing the standby heat loss rate, which also reduces the heat content of the stored water, is to utilize a tank of smaller volume. If the smaller heater is assumed to have the same quality and thickness 
of insulation as a larger heater, the total heat loss rate will be smaller because the surface area of the tank is smaller. However, the heat loss rate decreases less rapidly than the volume, so the smaller heater will have a greater heat loss rate per gallon of water (at a given temperature) than the larger heater.

Changes in lifestyle can compensate for a lower stored-heat content in the water heater. The heavier hot-water uses must be scheduled far enough apart for the heater to recover between uses. Other changes in habits can yield energy conservation in the total amount of hot water used. For example, the shower head can be restricted to $3 \mathrm{gal} / \mathrm{min}(11.4$ liters/min), rather than the $10 \mathrm{gal} / \mathrm{min}$ (37.85 1iters $/ \mathrm{min}$ ) or more of which most are capable. A 5 -min shower at $3 \mathrm{gal} / \mathrm{min}$ ( 11.4 liters/min) uses nine times less water than a $15-\mathrm{min}$ shower at $9 \mathrm{gal} / \mathrm{min}$ (34.07 liters/min). For a family of four, the monthly cost of daily showers at $0.0345 \$ / \mathrm{kWhr}$ is $\$ 8.48$ for the economy showers as compared with $\$ 76.28$ for the long, luxury showers [assuming an average ground water temperature for the year of $\left.55^{\circ} \mathrm{F}\left(12.8^{\circ} \mathrm{C}\right)\right]$. For maximum energy efficiency, dishwashers and clothes washers should be operated only when full, and the hot water should not be allowed to run continuously when shaving. It may be possible to do laundry in cold water, if suitable detergents are used.

Some other energy-conserving measures do not affect lifestyles. Retrofit insulation of electric water heaters (but not gas-fired water heaters, for reasons of safety) using $\mathrm{R}-11$ home insulation is highly cost effective (see Sect. 4). Also, the location of the water heater can markedly affect the standby heat loss rate. Ideally the heater should be coupled to the living quarters in the heating season so that advantage may be taken of its heat loss rate, and decoupled in the cooling season so that the heat loss. rate will not have to be removed by the air conditioner. Heaters are found in almost any conceivable location in the home, and the degree of coupling to the living quarters varies widely. In mobile homes, for example, the water heater is frequently located near the outer wall. One could conserve energy by having removable panels so that in the winter the heater is coupled to 
the living quarters, and in the summer it is coupled to the outside by a removable panel on the outside wall. Insulation of hot-water pipes is only marginally cost effective because the amount of stored heat is small. Hot-water pipes should definitely not be cast into concrete floor slabs, which will act as large and effective heat sinks.

Energy conservation measures in the future may include solar heating of hot water and heat-pump water heaters. The latter could heat water at a coefficient of performance (heat output/heat input) approaching 3 , instead of unity as for resistance heating. 


\section{THIS PAGE}

\section{WAS INTENTIONALLY LEFT BLANK}




\section{ECONOMIC ANALYSIS OF STORAGE-TYPE WATER HEATERS}

\subsection{Gas-Fired Water Heaters}

The economic virtues of the previously mentioned water-heater modifications need to be examined with regard to the present worth of the annual savings derived from such modifications. This will give an upper limit to the cost increment for the modifications that will still leave the homeowner with a positive savings after alternative uses for the money are considered. The alternate use to be followed is the investment of the money at $9 \%$ interest compounded annually for the expected life of the water heater, which will be taken as 10 years. The present worth, $P$, of a series of annual savings is $R\left[1-(1+i)^{-n}\right] / i$, wherc $R$ is the annual saving, $i$ is the compound interest rate per year, and $\mathrm{n}$ is the number of years under consideration. In the present case, $i=0.09$ and $n=10$ are assumed. For a $\$ 1.00$ annual saving, the present worth is $\$ 6.42$; for example, if a modification to the water heater saves $\$ 1.00$ per year, then $\$ 6.42$ can be invested in the modification at the beginning of the service life and still return to the homeowner the same amount as the money invested at $9 \%$ for 10 years.

The annual operating costs to be considered will be those of a family of four using $75 \mathrm{gal}\left(0.284 \mathrm{~m}^{3}\right)$ of hot water per day heated through a temperature rise of $95^{\circ} \mathrm{F}\left(52.8^{\circ} \mathrm{C}\right.$ ) [for example, from 55 to $150^{\circ} \mathrm{F}\left(12.8\right.$ to $\left.\left.65.6^{\circ} \mathrm{C}\right)\right]$. If a thermostat setting lower than $150^{\circ} \mathrm{F}$ $\left(65.6^{\circ} \mathrm{C}\right)$ is specified, then it is assumed that the energy content of the hot water used will still be the same as if the thermostat were set for $150^{\circ} \mathrm{F}\left(65.6^{\circ} \mathrm{C}\right)$.

The yearly operating costs for the above scenario are shown in Table 8 for the same configurations treated in Table 3: flue blocked between firings of the main burner, with the jacket losses supplied by the main burner; flue open and pilot off between firings of the main burner, with the jacket and pilot-off flue losses supplied by firings of the main burner; and flue open and pilot on between firings of the main burner (as-received), with the net water-tank loss rate supplied by the 
Table 8. Operating costs and savings with pilot off and flue open or blocked during standby for a gas-fired water heater ${ }^{a}$

\begin{tabular}{|c|c|c|c|}
\hline & Water & temperature, &,${ }^{\circ} \mathrm{F}$ \\
\hline & 110 & 130 & 150 \\
\hline $\begin{array}{l}\text { As-received configuration } \\
\text { Annual operating cost, } \$ / \text { year }^{b}\end{array}$ & 71.25 & 78.10 & 88.46 \\
\hline $\begin{array}{l}\text { Pilot off, flue open } \\
\text { Annual operating cost, } \$ / \text { year }^{b} \\
\text { Annual saving compared to as-received, } \\
\quad \$ / \text { year } \\
\text { Present worth of } 10 \text { years' savings, } \$^{c}\end{array}$ & $\begin{array}{r}68.65 \\
2.60\end{array}$ & $\begin{array}{r}76.38 \\
1.72\end{array}$ & $\begin{array}{r}85.79 \\
2.67\end{array}$ \\
\hline $\begin{array}{l}\text { Pilot off, flue blocked } \\
\text { Annual operating cost, } \$ / \text { year } b \\
\text { Annual saving compared to as-received, } \\
\quad \$ / \text { year } \\
\text { Present worth of } 10 \text { years' savings, } \$^{c}\end{array}$ & $\begin{array}{r}64.82 \\
6.43\end{array}$ & $\begin{array}{r}69.62 \\
8.48\end{array}$ & $\begin{array}{l}75.57 \\
12.89\end{array}$ \\
\hline
\end{tabular}

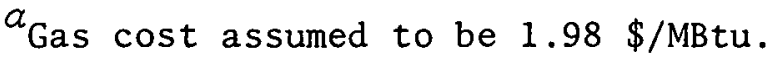

$b_{\text {Operation includes supplying hot water with heat content equivalent }}$ to $75 \mathrm{gal} / \mathrm{day}$ of water that has been heated through a $95^{\circ} \mathrm{F}$ temperature rise.

${ }^{c}$ Present worth computed at $9 \%$ interest, 10-year 1 ife.

main burner. In the case of the gas-fired water heater with the pilot on, the cost of the standby heat loss rate and the cust of the heat required to raise the temperature of the inconing water are not simply additive, because the main burner supplies losses at a higher heatexchange efficiency while it is on.

As shown in Table 8 , sizable savings can be realized by lowering the thermostat setting if the final temperature and stored-heat content are adequate. No present worth can be assigned to this conservation measure, since it is free. Electric ignition (flue open and pilot off between main burner firings) would yield marginal returns if applied without flue blocking. The maximum cost of this device to the homeowner could not exceed $\$ 10.00$ to $\$ 15.00$ additional for cost effectiveness. 
Blocking of the flue in addition yields appreciable savings over electric ignition alone. The additional acceptable equipment cost is $\$ 40.00$ to $\$ 80.00$.

The orifice restriction and power burner were evaluated only for the retrofitted $\mathrm{R}-11$ insulation configuration. The power burner was not characterized for the full range of water-tank temperatures, so the economic analysis for these configurations will encompass only the retrofit insulation and a water temperature of $150^{\circ} \mathrm{F}\left(65.6^{\circ} \mathrm{C}\right)$. The results are shown in Table 9. The present-worth values are calculated relative to the as-received configuration of the water heater, with a standing pilot. The savings allocated to the retrofit insulation are abstracted in Table 9. It is clear that retrofit insulation is highly cost effective. The savings are about $\$ 10.60 /$ year, and the cost of the materials required to insulate a heater is about $\$ 6.00$ (retrofit insulation of gas-fired water heaters must not be attempted by the homeowner). The return over the useful life of the heater would then be about $\$ 62.00$. l'he present worth of the flue blocked, orifice restriction, and power burner modifications is more than the present retail cost (about $\$ 115.00$ ) of a new gas-fired 50-gal water heater. These modifications should be highly cost effective.

Compared with the orifice restriction, the power burner derives its improved cost performance from the higher main burner efficiency [at $150^{\circ} \mathrm{F}\left(65.6^{\circ} \mathrm{C}\right), 85 \%$ as compared with $\left.73 \%\right]$. The cost of raising the temperature of the input water is $\$ 8.15$ lower for the power burner, but. this advantage is reduced to $\$ 4.85$ because of the lower pilot heatexchange efficiency. The pilot burner excess-air ratio was not optimized, so improvements in the pilot heat-exchange efficiency are possible.

\subsection{Electric Water Heaters}

The standby jacket heat loss rates of the two electric water heaters in the various retrofitted insulation configurations listed in Table 6 are translated into annual savings in Table 10. The savings are remarkably high because the cost of electricity (at $3.45 \$ / \mathrm{kWhr}$ ) is $10.11 \$ / \mathrm{MBtu}$ as opposed to 1.98 \$/MBtu for gas. However, the gas is 
Table 9. Operating costs of as-received and modified gas-fired water heater while delivering $75 \mathrm{gal} /$ day of $150^{\circ} \mathrm{F}$ hot water ${ }^{\alpha}$

\begin{tabular}{|c|c|c|c|}
\hline Configuration & $\begin{array}{l}\text { Annual } \\
\text { operating cost } \\
(\$ / y r)\end{array}$ & $\begin{array}{l}\text { Savings compared } \\
\text { with as-received } \\
(\$ / y r)\end{array}$ & $\begin{array}{c}\text { Present worth } \\
\text { of savings } \\
(\$)\end{array}$ \\
\hline As-received & 88.46 & & \\
\hline Pilot off & 85.79 & 2.67 & 17.14 \\
\hline Pilot off, flue blocked & 75.57 & 12.89 & 82.75 \\
\hline $\begin{array}{l}\text { Retrofit insulation } \\
\text { Pilot on } \\
\text { Pilot off } \\
\text { Pilot off, flue blocked } \\
\text { Flue orifice restriction } \\
\text { Power burner }\end{array}$ & $\begin{array}{l}77.83 \\
75.10 \\
64.96 \\
65.06 \\
60.21\end{array}$ & $\begin{array}{l}10.63 \\
13.36 \\
23.50 \\
23.40 \\
28.25\end{array}$ & $\begin{array}{r}68.24 \\
85.77 \\
150.87 \\
150.23 \\
181.37\end{array}$ \\
\hline $\begin{array}{l}\text { Savings attributable to retrof } \\
\text { insulation only } \\
\text { Pilot on } \\
\text { Pilot off } \\
\text { Pilot off, flue blocked }\end{array}$ & & $\begin{array}{l}10.63 \\
10.69 \\
10.61\end{array}$ & $\begin{array}{l}68.24 \\
68.63 \\
68.12\end{array}$ \\
\hline
\end{tabular}

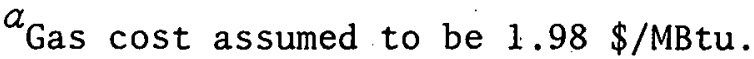

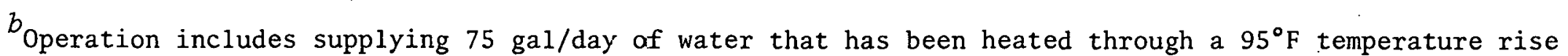
(heat equivalent $=58,282 \mathrm{Btu} /$ day) .

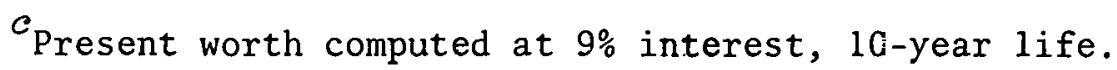


Table 10. Cost of standby heat losses for electric water heater ${ }^{a}$

\begin{tabular}{|c|c|c|c|c|c|c|c|}
\hline \multirow[b]{2}{*}{$\begin{array}{l}\text { Water } \\
\text { temp. } \\
\left(^{\circ} \mathrm{F}\right)\end{array}$} & \multirow[b]{2}{*}{$\begin{array}{l}\text { As-received } \\
\text { anrual cost } \\
\quad(\$ / \text { year })\end{array}$} & \multicolumn{3}{|c|}{$11 / 2$-in. retrofit insulation } & \multicolumn{3}{|c|}{$31 / 2$-in. retrofit insulation } \\
\hline & & $\begin{array}{c}\text { Annual } \\
\text { costb } \\
(\$ / \text { year })\end{array}$ & $\begin{array}{l}\text { Annual } \\
\text { saving } \\
(\$ / \text { year })\end{array}$ & $\begin{array}{c}\text { Present worth } \\
\text { of savings } \\
(\$)\end{array}$ & $\begin{array}{c}\text { Annual } \\
\text { cost } b \\
(\$ / \text { year })\end{array}$ & $\begin{array}{l}\text { Annual } \\
\text { saving } \\
(\$ / \text { year })\end{array}$ & $\begin{array}{c}\text { Present worth } \\
\text { of savings } \\
(\$)\end{array}$ \\
\hline \multicolumn{8}{|c|}{ 66-gal heater } \\
\hline 110 & 27.92 & 20.12 & 7.80 & 50.08 & 18.26 & 9.66 & 62.02 \\
\hline 130 & 43.16 & 31.11 & 12.05 & 77.36 & $28.81^{\circ}$ & 14.35 & 92.13 \\
\hline 150 & 58.50 & 42.72 & 15.78 & 101.31 & 39.53 & 18.97 & 121.79 \\
\hline \multicolumn{8}{|c|}{ 30-gal heater } \\
\hline 110 & 23.49 & & & & 13.38 & 10.11 & 64.91 \\
\hline 130 & 37.23 & . & & & 22.69 & 14.54 & 93.35 \\
\hline 150 & 51.14 & & & & 31.91 & i 9.23 & 123.46 \\
\hline
\end{tabular}

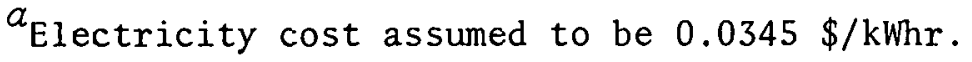

${ }^{b}$ For the total operating cost, add the cost of heating 75 gal/day through a $95^{\circ} \mathrm{F}$ temperature rise, or $\$ 215.24$ per year.

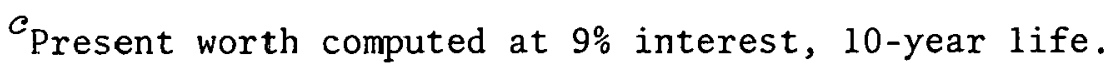


utilized at about a $73 \%$ heat-exchange efficiency, so the cost of gas is $\$ 1.98 / 0.73$, or $2.71 \$ /$ MBtu $\left(2.57 \$ / 10^{9} \mathrm{~J}\right)$ actually delivered to the water tank. In all cases, the cost of the $\mathrm{R}-11$ retrofit insulation $(\$ 5.00$ to $\$ 6.00)$ is returned within one year, with present worths ranging to an appreciable fraction of the cost of a new heater [\$175 for a 66-gal $\left(0.25-\mathrm{m}^{3}\right)$ electric, fast-recovery water heater]. The $11 / 2-i n$. $(3.81-\mathrm{cm})$ retrofit insulation consists of a commercially supplied kit that includes glass fiber insulation with a flame-proof vinyl sheet backing, which results in a neat installation. Although this kit decreased the heat loss rate less than for the $\mathrm{R}-11$ insulation and cost more ( $\$ 10.00$ to $\$ 20.00$ retail), it is still quite cost effective. The cost to heat 75 gal $\left(0.28 \mathrm{~m}^{3}\right)$ of water per day through a temperature rise of $95^{\circ} \mathrm{F}\left(52.8^{\circ} \mathrm{C}\right)$ is $\$ 215.24 /$ year, which should be added to the figures in Table 10 to determine the total cost of operating the heater.

\subsection{Indirect Energy Usage of Storage-Type Water Heaters}

A water heater may properly be charged with both its direct consumption of energy and with the energy that it, by its operation, causes to be consumed. If a gas-fired water heater is located within the conditloned llvilly space, the airflow out of the shimney ranses infiltration of makeup air, which must be conditioned by the spaceheating and air-conditioning installation in the house. The jacket heat loss rate, if needed, aids in space heating; conversely, this heat must be removed during periods of space cooling. These considerations apply only to the degree that the water heater space is coupled to the living space.

Chimney airflows induced by a water heater (similar to the water heater tested in the laboratory) inside a residence were measured. The chimney airflow was 1.39 times the flue airflow with the pilot on and 1.93 times the flue airflow with the main burner on. Using the measured flue airflows from Table 2, the total chimney airflow was calculated as $17,163 \mathrm{ft}^{3} /$ day $\left(486 \mathrm{~m}^{3} /\right.$ day $)$ to deliver $75 \mathrm{gal}\left(0.28 \mathrm{~m}^{3}\right)$ of water and supply standby losses. Assuming an average specific volume for the heated air of $14.75 \mathrm{ft}^{3} / 1 \mathrm{~b}\left(0.92 \mathrm{~m}^{3} / \mathrm{kg}\right), 1164 \mathrm{lb} / \mathrm{day}(528 \mathrm{~kg} / \mathrm{day})$ of air 
were conditioned. The heat required per Fahrenheit degree of temperature difference is $282 \mathrm{Btu} /{ }^{\circ} \mathrm{F}^{-1} \mathrm{day}^{-1}\left(1.65 \times 10^{5} \mathrm{~J} /{ }^{\circ} \mathrm{C}^{-1} \mathrm{day}^{-1}\right)$. A gas furnace operating at $50 \%$ efficiency ${ }^{2}$ would consume $562 \mathrm{Btu} /{ }^{\circ} \mathrm{F}^{-1} \mathrm{day}^{-1}$ $\left(3.3 \times 10^{5} \mathrm{~J} /{ }^{\circ} \mathrm{C}^{-1} \mathrm{day}^{-1}\right)$ to supply this heat. The cost per month, at . $1.98 \$ / \mathrm{MBtu}\left(1.88 \$ / 10^{9} \mathrm{~J}\right)$, would be $0.034 \$ /{ }^{\circ} \mathrm{F}^{-1} \mathrm{mo}^{-1}\left(0.061 \$ /^{\circ} \mathrm{C}^{-1} \mathrm{mo}^{-1}\right)$, or $1.02 \$ /$ month for an average temperature difference of $30^{\circ} \mathrm{F}\left(16.7^{\circ} \mathrm{C}\right)$. This is an appreciable fraction of the $2.30 \$ /$ month standby cost of maintaining the gas-fired water heater at $150^{\circ} \mathrm{F}\left(65.6^{\circ} \mathrm{C}\right)$ in the asreceived configuration. During a hot month in which the outside temperature remained above a set point of $78^{\circ} \mathrm{F}\left(25.6^{\circ} \mathrm{C}\right)$ for $200{ }^{\circ} \mathrm{F}$-days (111 ${ }^{\circ} \mathrm{C}$-days), the total heat to be removed from the living space would be $282 \mathrm{Btu} /{ }^{\circ} \mathrm{F}$-day $\left(1.65 \times 10^{5} \mathrm{~J} /{ }^{\circ} \mathrm{C}^{-1}\right.$ day $\left.{ }^{-1}\right)$ times $200{ }^{\circ} \mathrm{F}$-days $\left(111^{\circ} \mathrm{C}\right.$-days $)$, or $56,400 \mathrm{Btu}\left(3.2 \times 10^{6} \mathrm{~J}\right)$. An air conditioner operating with an energy-efficiency ratio of $7 \mathrm{Btu} / \mathrm{Whr}(2 \mathrm{~J} / \mathrm{J})$ would consume 8057 Whr $\left(29 \times 10^{7} \mathrm{~J}\right)$, which would cost $\$ 0.28$ for the month.

The jacket heat loss rate of a gas-fired water heater or an electric water heater contributes to the space heating during the heating season if the appliance is located in the living space. The degree to which credit may be taken for a constant, uncontrollable heat source in the living space is arguable. The electric heater may be said to be $100 \%$ efficient under these conditions, but not for heating water. For the gas-fired water heater at $150^{\circ} \mathrm{F}\left(65.6^{\circ} \mathrm{C}\right), 92 \%$ of the pilot burner heat input goes up the flue, so it contributes very little to space heating. Also, energy used to warm the incoming air helps to offset any heating credic. Many water heaters are located in spaces that are loosely coupled to the living space; therefore, credit can be taken for the jacket heat loss rate only if the details of the installation are closely defined.

The jacket heat loss rate must be removed by the air-conditioning system during the cooling season. Table 11 shows the cost per month of continuous air conditioning for removing this heat rate. If the airconditioning system runs for one continuous month of the year, the extra insulation pays for itself by reducing the air-conditioning load for some of the situations. For example, the gas water heater at $150^{\circ} \mathrm{F}\left(65.6^{\circ} \mathrm{C}\right)$ 
Table 11. Cost per month of continuous air conditioning to remove water heater jacket loss from conditioned space ${ }^{\text {to }}$

Heater type and configuration

\begin{tabular}{cc} 
Water temperature, & ${ }^{\circ} \mathrm{F}$ \\
\hline 110 & 130
\end{tabular}

Gas heater, as received

$\$ 1.31$

$\$ 2.01$

$\$ 2.70$

Gas heater, 3 1/2-in. retrofit insulation

0.60

0.84

1.09

Electric heater, 66-gal, as received

1.13

1.75

2.38

Electric heater, 66-gal, 3 1/2-in.

0.74

1.17

1.61 retrofit insulation.

$a_{\text {Monthly operating cost computed on basis of air conditioner energy }}$ efficiency ratio of $7.0 \mathrm{Btu} / \mathrm{Whr}$ and electricity cost of $0.0345 \$ / \mathrm{kWh}$.

requires $\$ 1.61$ less per continuous month of running for heat removal if it is, insulated with R-11 glass fiber insulation. This saving, over a 10 -year period, has a present worth of $\$ 10.34$. 


\section{SUMMARY AND CONCLUSIONS}

The heat loss through the jacket is the only major heat loss mechanism for the electric water heater, and is one of the two heat loss mechanisms for the gas-fired water heater. At a tank temperature of $150^{\circ} \mathrm{F}\left(65.6^{\circ} \mathrm{C}\right)$ and an ambient temperature of $70^{\circ} \mathrm{F}\left(21.1^{\circ} \mathrm{C}\right)$, the retrofit of $31 / 2$ in. $(8.9 \mathrm{~cm})$ of glass fiber insulation reduced the 66-gal $\left(0.25-\mathrm{m}^{3}\right)$ electric water heater jacket heat loss rate to $68 \%$, and the gas-fired water hcater jacket lieat loss rate to $40 \%$ of that without the extra insulation. The cost of the extra insulation (about $\$ 6.00$ ) would be paid back to the homeowner through energy savings in about 4 months for the electric water heater and in about 7 months for the gas-fired water heater. We conclude that more insulation should be installed at the factory on both types of heaters, and existing electric water heaters should have additional insulation retrofitted.

The other major heat loss mechanisı for the gas-fired water heater is the flue. The flue loss percentage is particularly high for the pilot burner because it must operate with an excess-air ratio of about 50 , caused by the necessary sizing of the flue for the main burner. The pilot flue loss for the gas-fired water heater was measured as $58 \%$ at $110^{\circ} \mathrm{F}\left(43.3^{\circ} \mathrm{C}\right)$ and $92 \%$ at $150^{\circ} \mathrm{F}\left(65.6^{\circ} \mathrm{C}\right)$. This was reduced to $22 \%$ at $110^{\circ} \mathrm{F}\left(43.3^{\circ} \mathrm{C}\right)$ and about $28 \%$ at $150^{\circ} \mathrm{F}\left(65.6^{\circ} \mathrm{C}\right)$ by flue restriction to a 5/16-in. $(0.79-\mathrm{cm})$ orifice. The pilot flue loss was eliminated completely by blocking the flue during standby conditions. Provision must be made for reiluving the flue restriction or block by mechanical or electrical means whenever the main burner is on, and for igniting the main burner electrically when the flue block is removed.

An electrically powered burner and improved flue baffle increased the heat-exchange efficiency of the main burner from about $72 \%$ at $160^{\circ} \mathrm{F}$ $\left(71.1^{\circ} \mathrm{C}\right)$ to about $85 \%$ at the same temperature. The combination of additional insulation and either flue restriction, flue blocking, or power burner was highly cost effective. The present worth of savings, computed at $9 \%$ interest for 10 years, for these configurations was about $\$ 150$, $\$ 151$, and $\$ 181$, respectively. 


\section{THIS PAGE}

\section{WAS INTENTIONALLY LEFT BLANK}




\section{REFERENCES}

1. Eric Hirst and Janet Carney, Residential Energy Use to the Year 2000: Conservation and Economics, ORNL/CON-17 (November 1977). [See also W. D. Lee and R. P. Wilson, Energy Saving Options for Refrigerators and Water Heaters, FEA Contract C0-04-50228-00 (March 1977), and J. J. Mutch, Residential Water Heating: Fuel Conservation, Economics, and Public Policy, Rand Corporation Report R-1498-NSF (May 1974).]

2. E. C. Hise and A. S. Holman, Heat Balance and Efficiency Measurements of Central, Forced-Air Residential Gas Furnaces, ORNL/NSF/EP-88 (October 1975).

3. American Nationdl Standards Institute, American National Standard for Gas Water Heaters, Volume I: Automatic Storage Heaters with Inputs of 75,000 Btu Per Hour or Less, ANSI 221.10.1-1974. 


\section{THIS PAGE}

\section{WAS INTENTIONALLY LEFT BLANK}


ORNL/CON-5

\section{INTERNAL DISTRIBUTION}

1. L. A. Abbatiello

2. S. I. Auerbach

3. M. Baker

4. V. D. Baxter

5. S. E. Beal1

6. D. J. Bjornstad

7. J. R. Buchanan

8. R. S. Carlsmith

9. W. S. Chern

10. C. V. Chester

11. F. A. Creswick

12. R. M. Davis

13. J. G. Delene

14. R. D. Ellison

15. W. Fulkerson

16. V. 0. Haynes

17. N. E. Hinkle

18. E. A. Hirst

19. E. C. Hise

20. A. S. Holman

21. C. C. Hopkins

22. P. L. Johnson

23. S. I. Kaplan

24. D. Kaserman

25. R. S. Livingston

26. H. M. Long

27-46. P. M. Love

47. H. J. Metz
48. J. W. Michel

49-68. R. E. Minturn

69. W. R. Mixon

70. J. C. Moyers

71. E. A. Nephew

72. D. L. O'Neal

73. H. Postma

74. C. K. Rice

75. M. W. Rosenthal

76. T. H. Row

77. G. G. Slaughter

78. R. L. Spore

79. E. G. Struxness

80. T. Takayama

81. D. B. Trauger

82. G. U. Ulrikson

83. D. J. Walukas

84. T. J. Wilbanks

85. H. E. Zittel

86. A. Zucker

87. Biology Division Library

88-89. Central Research Library

90. Document Reference Section

91-92. Energy Information Library

93. Laboratory Records (RC)

94-96. Laboratory Records Dept.

97. ORNL Patent Office

\section{EXTERNAL DISTRIBUTION}

98. Mike Barganier, c/o C\&S Mortgage Company, 1619 Norcross-Tucker Road, Norcross, GA 30093

99. Ron Bishop, Johns-Manville Sales Corporation, P. O. Box 5108, Denver, CO 80217

100. J. 0. Collins, Johns-Manville Sales Corporation, Research and Development Center, Ken-Caryl Ranch, Denver, Co 80217

101. Vic Pappas, United Cities Gas Company, 1200 Parkway Towers, 404 James Robertson Parkway, Nashville, TN 37219

102. Bil1 late, Portland General Electric Company, 1212 GeurgiaPacific Boulevard, Portland, OR 97205

103. Institute of Energy Analysis, ORAU - Library

104. Research and Technical Support Division, DOE-ORO

105-131. Technical Information Center, DOE, P. O. Bux 62, Oak Ridge, TN 37830

132-600. Exterind Energy Conservation Distribution Mailing List and Energy Conservation Office, Building 9102-1, Room 2 